\title{
Using Soil Water to Control Ammonia Emission from Acid Soils with and Without Chicken Litter Biochar
}

\author{
Maru Ali ${ }^{1}$, Ahmed Osumanu Haruna ${ }^{1,2,3}$, Nik Muhamad Abd. Majid ${ }^{3}$, Walter Charles Primus ${ }^{4}$, Nathaniel Maikol ${ }^{1}$, \\ Audrey Asap ${ }^{1}$, Aini Nadzirah Naharuddin ${ }^{1} \&$ Alicia Vanessa Jeffary ${ }^{1}$ \\ ${ }^{1}$ Department of Crop Science, Faculty of Agriculture and Food Sciences, Universiti Putra Malaysia Bintulu \\ Campus, 97008 Bintulu, Sarawak, Malaysia \\ ${ }^{2}$ Agriculture and Environment, Borneo Eco-Science Research Center, Faculty of Agriculture and Food Sciences, \\ Universiti Putra Malaysia Bintulu Sarawak Campus, 97008 Bintulu, Sarawak, Malaysia \\ ${ }^{3}$ Institute of Tropical Forestry and Forest Products (INTROP), Universiti Putra Malaysia, 43400 Serdang, \\ Selangor, Malaysia \\ ${ }^{4}$ Department of Basic Science and Engineering, Faculty of Agriculture and Food Sciences, Universiti Putra \\ Malaysia Bintulu Campus, 97008 Bintulu, Sarawak, Malaysia
}

Correspondence: Ahmed Osumanu Haruna, Department of Crop Science, Faculty of Agriculture and Food Sciences, Universiti Putra Malaysia Bintulu Campus, 97008 Bintulu, Sarawak, Malaysia. E-mail: osumanuharuna@gmail.com

Received: December 14, 2018 Accepted: December 28, 2018 Online Published: May 14, 2019

doi:10.5539/sar.v8n3p23

URL: https://doi.org/10.5539/sar.v8n3p23

\begin{abstract}
Although urea use in agriculture is on the increase, increase in $\mathrm{pH}$ at soil microsite due to urea hydrolysis which causes ammonia emission can reduce $\mathrm{N}$ use efficiency. Among the interventions used to mitigate ammonia loss include urease inhibitors, clinoptilolite zeolite, coated urea, and biochar but with little attention to the use of soil water levels to control ammonia volatilization. The objective of this study was to determine the effects of soil water levels on ammonia volatilization from soils with and without chicken litter biochar. Dry soils with and without chicken litter biochar were subjected to $0 \%, 25 \% 50 \%, 75 \%, 100 \%$, and $125 \%$ soil water. There was no urea hydrolysis in the soil without water. Chicken litter biochar as soil amendment effectively mitigated ammonia loss at $1 \%$ to $32 \%$ and $80 \%$ to $115 \%$ field capacity. However, urea used on soil only showed lower ammonia loss at $33 \%$ to $79 \%$ and $116 \%$ to $125 \%$ field capacity compared with the soils with chicken litter biochar. At 50\% field capacity ammonia loss was high in soils with and without chicken litter biochar. Although chicken litter biochar is reputed for improving soil chemical properties, water levels in this present study affected soil chemical properties differently. Fifty percent field capacity, significantly reduced soil chemical properties. These findings suggest that timely application of urea at the right field capacity can mitigate ammonia emission. Therefore, whether soils are amended with or without chicken litter biochar, urea application should be avoided at $50 \%$ field capacity especially in irrigated crops.
\end{abstract}

Keywords: ammonia volatilization, chicken litter biochar, soil water, urea hydrolysis

\section{Introduction}

The ever-increasing human population has caused increased use of nitrogen fertilizers in agriculture (Gellings \& Parmenter, 2016). Although ammonium nitrate and ammonium sulphate are used in agriculture, granular urea is the most used chemical fertilizer. For example, approximately 190 million tons of urea is used yearly out of which $80 \%$ is used in food production (Zhang et al., 2015). Urea is popular in developing countries because of its high nitrogen content and easy transportation (Glibert et al., 2006). However, increase in $\mathrm{pH}$ at soil microsite due to urea hydrolysis can accelerate ammonia emission. Urea-N loss through ammonia volatilization causes low $\mathrm{N}$ use efficiency (Sommer et al., 2004; Jensen et al., 2011; Martins et al., 2015). Ammonia volatilization from urea occurs when urea is hydrolysed by water to produce ammonium carbonate $\left[\mathrm{NH}_{2} \mathrm{CONH}_{2}+2 \mathrm{H}_{2} \mathrm{O}-\right.$ $\left(\mathrm{NH}_{4}\right)_{2} \mathrm{CO}_{3}$ ]. Afterwards, ammonium carbonate decomposes to produce ammonia, carbon dioxide, and water (Palanivell et al, 2017). Nitrogen loss through ammonia volatilization does not only cause economic loss to farmers but it also causes environmental pollution and human lung failure (Bremner, 1995). 
Although the literature is replete with information on ammonia volatilization from organic and mineral fertilizers (Sommer \& Hutchings, 2001; Sommer et al., 2004), the increasing use of urea due to high nitrogen demanding cultivars used in production agriculture has compelled researchers to come out with more effective means of mitigating ammonia volatilization. One of the approaches being adopted is the use of urease inhibitors to retard urea hydrolysis (Jia et al., 2015; Abalos et al., 2012; Francisco et al., 2011). Although, this approach decreases $\mathrm{NH}_{4}{ }^{+}$concentration in soil solution (Gill et al., 1999), the building up of $\mathrm{NH}_{4}{ }^{+}$in soils without it being timely used by crops will result in higher $\mathrm{NH}_{4}{ }^{+}$concentration in the soil solution. Higher concentration of $\mathrm{NH}_{4}{ }^{+}$in soil solution could also increase soil $\mathrm{OH}^{-}$ions such that the ions could re-react with $\mathrm{NH}_{4}{ }^{+}$to produce ammonia and $\mathrm{H}_{2} \mathrm{O}$ (Jia et al., 2015). The ammonia produced could be emitted into the environment regardless of urease inhibitors. Ahmed et al. (2010) and Palanivell et al. (2016) also used Clinoptilolite zeolite to mitigate ammonia volatilization from aerobic and anaerobic soil with urea, besides improving soil chemical properties. However, accessibility of good Clinoptilolite zeolite even for research purposes has been an issue. Another invention is coating urea with humic acids which had been reported to significantly minimize Urea-N loss through ammonia volatilization (Ahmed et al. 2010). The afore-stated innovations are good but they are expensive for farmers to adopt.

In recent times, some researchers are using organic amendments to control ammonia loss but among the organic amendments, biochars are preferred because they also improve soil CEC, texture, cations, and anions. Biochars are able to minimize ammonia volatilization because of their high surface charges. These charges which enable sorption of ammonium ions from being converted to ammonia (Rondon et al., 2006). Palanivell et al. (2017) used chicken litter biochar to reduce ammonia emission from a tropical acid soil (Typic Paleudults). However, there is a dearth of information on how soil water levels affect ammonia volatilization from tropical acid soils with chicken litter biochar and urea. If soil water minimize ammonia volatilization, it could be used as a cheaper method to improve nitrogen use efficiency in agriculture. Therefore, this study seeks to address the following research questions: (1) will soil water affect ammonia volatilization from soils with and without chicken litter biochar? and (2) what will be the suitable amount of soil water that could minimize ammonia volatilization from soils with and without chicken litter biochar? The objective of this study was to determine the effects of soil water levels on ammonia volatilization from soils with and without chicken litter biochar.

\section{Materials and Methods}

Typic Paleudults (Nyalau Series) soil was taken at 0 to $25 \mathrm{~cm}$ depth in a secondary forest of Universiti Putra Malaysia Bintulu Campus, Sarawak, Malaysia (latitude $3^{\circ} 12^{\prime} 14.5^{\prime \prime} \mathrm{N}$ and longitude $113^{\circ} 4^{\prime} 16.0^{\prime \prime} \mathrm{E}$ ). Afterwards, the soil was air dried and ground to pass a $5 \mathrm{~mm}$ sieve for pot trial and some were further sieved to pass a $2 \mathrm{~mm}$ sieve for selected chemical and physical properties analyses before and after incubation study (Table 1).

Soil $\mathrm{pH}$ was determined in a ratio of 1:2.5 (soil: distilled water) using a digital $\mathrm{pH}$ meter (Peech et al., 1965). Soil total $\mathrm{C}$ was calculated as $58 \%$ of the organic matter using the loss of weight on ignition method (Cheftez et al., 1996). Cation exchange capacity (CEC) of the soil was determined using the leaching method (Cottenie, 1980) followed by steam distillation (Bremner, 1965). Exchangeable cations were extracted with $1 \mathrm{M} \mathrm{NH}_{4} \mathrm{OAc}$ using the leaching method (Cottenie, 1980) after which, the cations were determined using Atomic Absorption Spectrometer (AAnalyst 800, PERKIN Elmer Instruments, Norwalk, CT). Total N was determined using Kjeldhal method (Tan, 2005) whereas $\mathrm{NO}_{3}{ }^{-}$and $\mathrm{NH}_{4}{ }^{+}$were determined using Keeney \& Nelson (1982) method. Total $\mathrm{P}$ and $\mathrm{K}$ were extracted using aqua regia method and thereafter, total $\mathrm{P}$ was determined using Spectrophotometer after blue colour was developed using the Blue Method (Murphy \& Riley, 1962). Total K was determined using Atomic Absorption Spectrometry (AAnalyst 800, Perkin Elmer Instrument, Norwalk, CT). Soil exchangeable acidity, $\mathrm{H}^{+}$, and $\mathrm{Al}^{3+}$ were determined using acid-base titration method (Rowell, 1994). These chemical analyses were repeated after the incubation study. The results of the initial soil chemical properties (Table 1) are similar those of Palanivell et al. (2017). 
Table 1. Selected chemical properties of Typic Paleudults (Bekenu Series) soil before ammonia volatilization study

\begin{tabular}{|c|c|c|c|}
\hline Properties & Values & Properties & Values \\
\hline \multirow[t]{2}{*}{$\mathrm{pH}$ in water } & $4.9 \pm 0.04$ & & $\ldots \ldots \mathrm{cmol} \mathrm{kg}^{-1} \ldots \ldots$ \\
\hline & $\ldots \ldots \ldots \%$.......... & Available K & $1.01 \pm 0.12$ \\
\hline Total carbon & $1.25 \pm 0.10$ & Total K & $3.30 \mathrm{a} \pm 1.14$ \\
\hline \multirow[t]{2}{*}{ Total N } & $0.05 \pm 0.007$ & CEC & $4.58 \pm 0.10$ \\
\hline & ...... $\mathrm{mg} \mathrm{kg}^{-1}$. & Exchangeable Acidity & $1.32 \pm 0.07$ \\
\hline Available $\mathrm{NO}_{3}^{-}$ & $1.05 \pm 0.35$ & Exchangeable $\mathrm{Al}^{3+}$ & $1.24 \pm 0.05$ \\
\hline Exchangeable $\mathrm{NH}_{4}{ }^{+}$ & $1.58 \pm 0.18$ & Exchangeable $\mathrm{H}^{+}$ & $0.08 \pm 0.02$ \\
\hline Available P & $2.84 \pm 0.64$ & Exchangeable $\mathrm{Cu}^{2+}$ & $0.0119 \pm 0.0006$ \\
\hline \multirow[t]{6}{*}{ Total P } & $64.80 \pm 4.64$ & Exchangeable $\mathrm{Mn}^{2+}$ & $0.27 \pm 0.07$ \\
\hline & & Exchangeable $\mathrm{Fe}^{2+}$ & $0.16 \pm 0.01$ \\
\hline & & Exchangeable $\mathrm{Zn}^{2+}$ & $0.0068 \pm 0.0008$ \\
\hline & & Exchangeable $\mathrm{Na}^{+}$ & $5.25 \pm 0.39$ \\
\hline & & Exchangeable $\mathrm{Ca}^{2+}$ & $26.39 \pm 2.76$ \\
\hline & & Exchangeable $\mathrm{Mg}^{2+}$ & $5.27 \pm 0.93$ \\
\hline
\end{tabular}

\subsection{Chemical Properties of Chicken Litter Biochar}

The Black Earth Products chicken litter biochar used in this study was imported from Australia. Chemical properties of the chicken litter biochar (Table 2) are consistent with Australia Certified Organic Standard, 2010. (Table 1).

Table 2. Selected chemical properties of BlackEarth chicken litter biochar

\begin{tabular}{llllll}
\hline \multicolumn{2}{l}{ Macro Nutrients } & \multicolumn{4}{c}{ Micro nutrients } \\
\hline $\mathrm{pH}$ & 8.5 & Av. Particle size & $0.5-2 \mathrm{~mm}$ \\
\hline$\ldots \ldots \ldots \ldots \ldots \ldots \ldots \ldots \ldots$ & $\ldots \ldots \ldots \ldots \ldots \ldots \ldots \ldots \ldots \mathrm{mg} \mathrm{kg}{ }^{-1} \ldots \ldots \ldots \ldots \ldots \ldots \ldots \ldots$ \\
\hline Total Carbon & 63.7 & Silicon & 2.3 & Magnesium oxide & 6.7 \\
Fixed Carbon & 61.2 & Aluminium & 1.5 & Arsenic & 2.1 \\
Nitrogen & 2.8 & Potassium oxide & 16.3 & Cadmium & 0.7 \\
Phosphate & 2.6 & Boron & 62 & Chromium & 9.6 \\
Potassium & 3.9 & Copper & 167 & Mercury & 0.06 \\
Calcium & 5.9 & Manganese & 1130 & Nickel & 14 \\
Sulphur & 0.59 & Zinc & 856 & Lead & 12 \\
Ash content & 23.7 & & \multicolumn{3}{c}{} \\
\hline
\end{tabular}

Source: Black Earth Company in North of Bendigo Victoria, Australia

Amount of the chicken litter biochar used was $5 \mathrm{tha}^{-1}$ (Maru et al., 2015) and this was scaled down according to the treatments evaluated (Table 3). The amount of urea used in this study was based on the recommendation of MADA (2015) and this was scaled down based on the requirement of rice plants hill (Table 2) (Palanivell et al., 2017). 
Table 3. Amounts of soil, chicken litter biochar, urea, and moisture levels used in the incubation study

\begin{tabular}{lllrl}
\hline Treatments & Soils & Chicken litter Biochar & Urea & Level of water per +soil field capacity \\
\hline & $\ldots \ldots \ldots \ldots \ldots \ldots \ldots . \mathrm{g} \ldots \ldots \ldots \ldots \ldots \ldots \ldots$ & $\ldots \ldots \% \ldots \ldots$. \\
T1 & 1000 & 20 & 1.32 & 0 \\
T2 & 1000 & 20 & 1.32 & 25 \\
T3 & 1000 & 20 & 1.32 & 50 \\
T4 & 1000 & 20 & 1.32 & 75 \\
T5 & 1000 & 20 & 1.32 & 100 \\
T6 & 1000 & 20 & 1.32 & 125 \\
T7 & 1000 & 0 & 1.32 & 0 \\
T8 & 1000 & 0 & 1.32 & 25 \\
T9 & 1000 & 0 & 1.32 & 50 \\
T10 & 1000 & 0 & 1.32 & 75 \\
T11 & 1000 & 0 & 1.32 & 100 \\
T12 & 1000 & 0 & 1.32 & 125 \\
\hline
\end{tabular}

\subsection{Ammonia Volatilization Setup}

Before setting up the ammonia volatilization study, soil was oven dried in an oven at $105{ }^{\circ} \mathrm{C}$ until constant weight was attained. This was done to remove hydroscopic water of the soil. Plastic containers were filled with 1 $\mathrm{kg}$ soil based on the soil's bulk density $\left(1.16 \mathrm{~g} \mathrm{~cm}^{-3}\right)$. Rates of the chicken litter biochar and amount of urea recommended by Maru et al. (2015) and MADA (2015), respectively were scaled down based on the requirement of the rice plants (Table 2). Ammonia volatilization was measured using a closed dynamic air flow system (Siva et al., 1999; Ahmed et al., 2006, Palanivell et al., 2017) with modification. The system consisted of air pumps which were connected to plastic containers with treatments using polyethene tubes (Figure 1). The incubation chambers were maintained at room temperature. Air was passed through the closed system at a rate of $3.5 \mathrm{~L}^{-1} \mathrm{~min}^{-1}$ chamber ${ }^{-1}$. This rate of airflow which is equivalent to 8.5 volume exchanges $\min ^{-1}$, was maintained throughout the incubation study using a Gilmont flow meter (Gilmont Instrument, Great Neck, NY, USA). The outlet of each container was connected to a conical flask with $75 \mathrm{~mL}$ boric acid solution using a polyethene tube. In the conventional method, only one conical flask with $75 \mathrm{~mL}$ boric acid solution is used but in this present study, three conical flasks connected in series using polyethene tubes were used (Figure 1). This modification is essential because the ammonia captured in the $75 \mathrm{~mL}$ of boric acid solution in only one conical flask requires accurate trapping of ammonia to avoid underestimation of this gas. Our preliminary trials revealed that excess ammonia got lost when only one conical flask with $75 \mathrm{~mL}$ boric acid solution was used due to saturation of the boric acid over 24 hours. Moreover, it was hard to know if the boric acid had captured enough ammonia for it to be changed within the 24 hours. However, with the three-capturing conical flasks with the boric acid solution in series, avoidance of the underestimation of ammonia loss was possible (Figure 1) as excess ammonia were captured in the boric acid solutions of the second and third conical flasks. This means that, with this new approach of using 3 sets of conical flasks each with $75 \mathrm{~mL}$ boric acid solution, all of the ammonia released within 24 hours were captured. The captured ammonia was back titrated with $0.01 \mathrm{M} \mathrm{HCl}$ to estimate the daily percentages of the ammonia released from urea. Measurements were continued until the ammonia loss declined to $1 \%$ of the $\mathrm{N}$ added from urea (Ahmed et al., 2006). Thereafter, the ammonia volatilization study was stopped, and the soil samples were processed and analysed using standard procedures outlined earlier. 


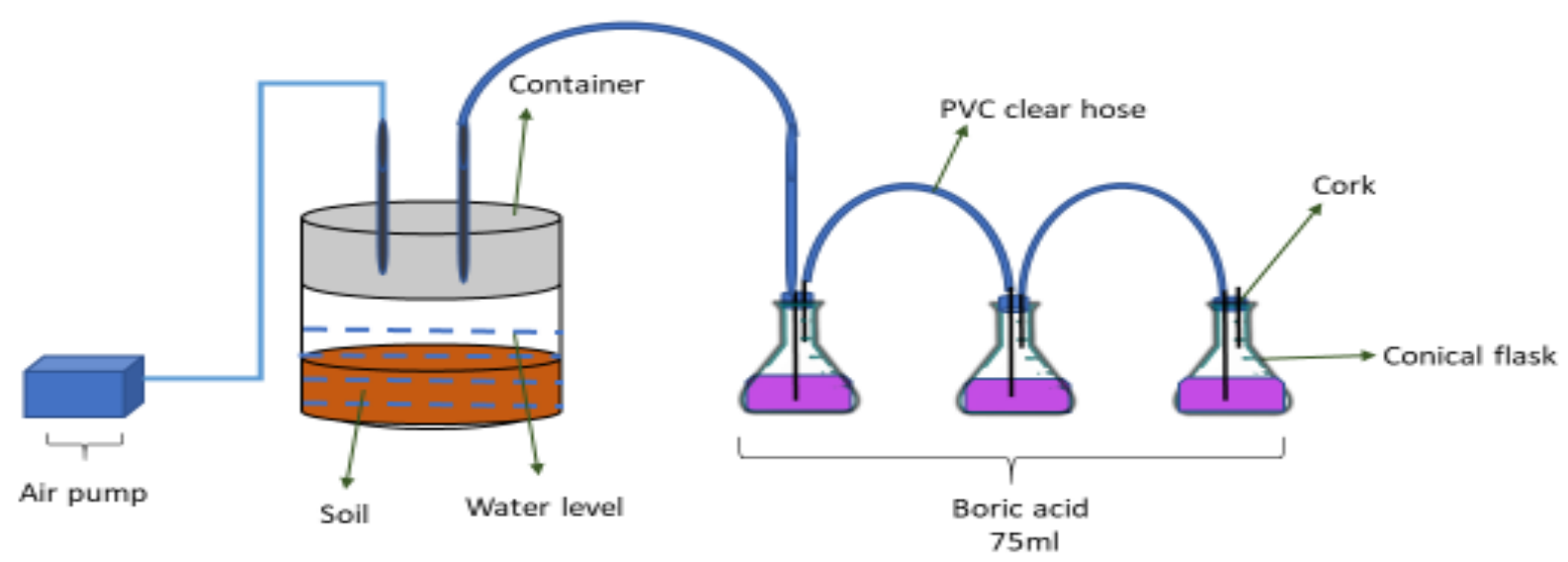

Figure 1. Close-dynamic air flow system (Siva et al., 1999; Ahmed et al., 2006) with modification

\subsection{Statistical Analysis}

Analysis of variance (ANOVA) was used to detect significant differences among treatments whereas Tukey's HSD test was used to compare treatment means using Statistical Analysis System version 9.2 (SAS, 2008).

\section{Results and Discussion}

\subsection{Water Levels on Ammonia Volatilization from Soils with Chicken Litter Biochar}

Urea reacts with soil water to produce unstable carbamic acid after which this acid decomposes to form ammonia and carbon dioxide (Equation 1) (Fan \& Mackenzie, 1993). However, there was no ammonia emission from T1 (Figures 2, 3, and 4) because of negligible amount of soil water as the soil was oven dried at $105^{\circ} \mathrm{C}$.

$$
\left(\mathrm{NH}_{2}\right)_{2} \mathrm{CO}+\mathrm{H}_{2} \mathrm{O} \rightarrow \mathrm{NH}_{3}+\mathrm{H}_{2} \mathrm{NCOOH} \rightarrow 2 \mathrm{NH}_{3} \text { (gas) }+\mathrm{CO}_{2}
$$

For $\mathrm{T} 2$, there was urea hydrolysis resulting in ammonia loss at $25 \%$ soil water and ammonia volatilization from this treatment was lower than that of T3 (50\% soil water) (Figures 2, 3, and 4) because of the lower soil water. In T3, ammonia volatilization increased significantly (Figures 2, 3, and 4) because there was enough soil water to hydrolyze urea to produce unstable carbamic acid $\left(\mathrm{NH}_{3}+\mathrm{H}_{2} \mathrm{NCOOH}\right)$ (Palanivell et al., 2017; Havlin et al. 1999) but not enough water to further convert carbamic acid to ammonium $\left(\mathrm{NH}_{4}{ }^{+}\right)$and carbon dioxide $\left(\mathrm{CO}_{2}\right)$ hence, the higher ammonia emission from T3 (Equations 1 and 2).

$$
\mathrm{NH}_{3}+\mathrm{H}_{2} \mathrm{O}+\mathrm{CO}_{2} \rightarrow \mathrm{NH}_{4}^{+}+\mathrm{CO}_{2}+\mathrm{OH}^{-}
$$

The total amounts of the ammonia emitted for 41 days further indicate that the ammonia loss from $\mathrm{T} 3$ was significantly higher than those of T1, T2, T4, T5, and T6 (Figure 3). At 75\% and 100\% soil water respectively, ammonia emissions from $\mathrm{T} 4$ and $\mathrm{T} 5$ were lower than that of $\mathrm{T} 3$ because of extra soil water to hydrolyze most of urea to $\mathrm{NH}_{4}{ }^{+}$(equation 2). The soil water might have diluted the concentration of $\mathrm{NH}_{4}{ }^{+}$in solution to minimize ammonia emission (Madrini et al., 2016).

The daily ammonia volatilization from T6 started on day 3 and this loss was similar to those reported by Palanivell et al. (2016) because urea hydrolysis is rapid in waterlogged soils. The waterlogged condition might have limited nitrification (convention of $\mathrm{NH}_{4}{ }^{+}$to $\mathrm{NO}_{3}{ }^{-}$) in $\mathrm{T} 6$ due to limited oxygen. As a result, higher $\mathrm{NH}_{4}{ }^{+}$ concentration in soil solution favours ammonification that is, reaction of $\mathrm{NH}_{4}{ }^{+}$with $\mathrm{OH}^{-}$to produce $\mathrm{NH}_{3}$ and $\mathrm{H}_{2} \mathrm{O}$ thereby causing the earlier ammonia emission from T6 (Figure 2). Ammonia loss from T6 (125\% soil water) was higher than those of $\mathrm{T} 4$ and $\mathrm{T} 5$ at $75 \%$ and $100 \%$ soil water, respectively, because production of $\mathrm{OH}^{-}$in waterlogged condition is higher due to complete urea hydrolysis. In complete urea hydrolysis, one mole of urea consumes two moles of $\mathrm{H}^{+}$ions from soil water to produce two moles of $\mathrm{OH}^{-}$(Liyanage et al., 2015). Thereafter, the hydroxyl ions react with $\mathrm{NH}_{4}{ }^{+}$to produce ammonia and water (Equation 3) (Palanivell et al., 2017; Havlin et al., 1999).

$$
\mathrm{NH}_{4}^{+}+\mathrm{OH}^{-} \rightarrow \mathrm{NH}_{3}+\mathrm{H}_{2} \mathrm{O}
$$




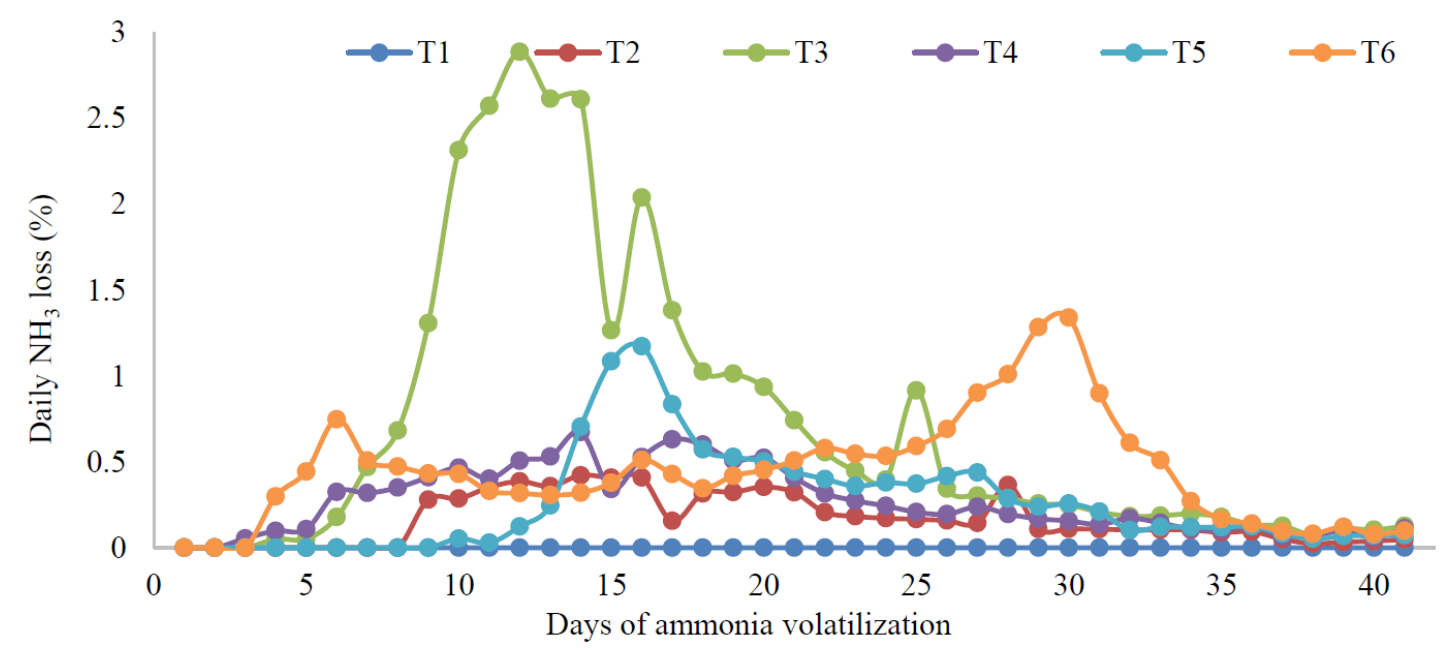

Figure 2. Water levels on daily ammonia volatilization from soil with chicken litter biochar

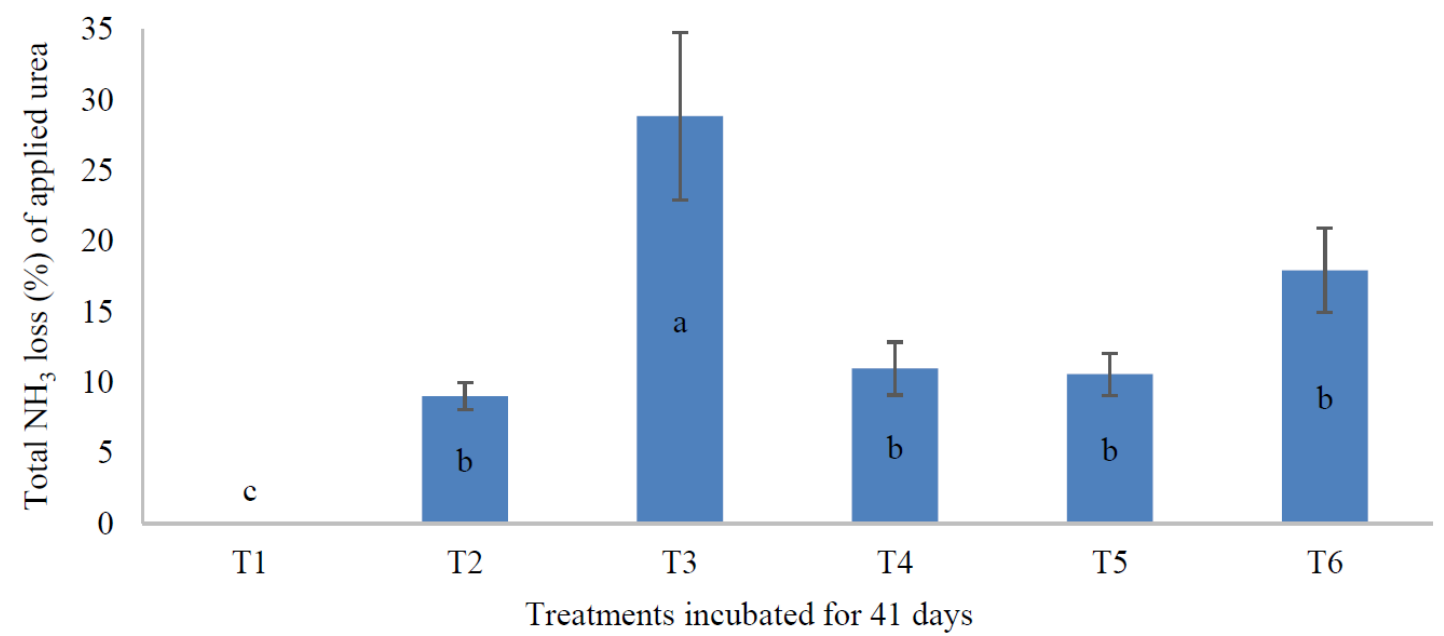

Figure 3. Water levels on total ammonia volatilization from soil with chicken litter biochar

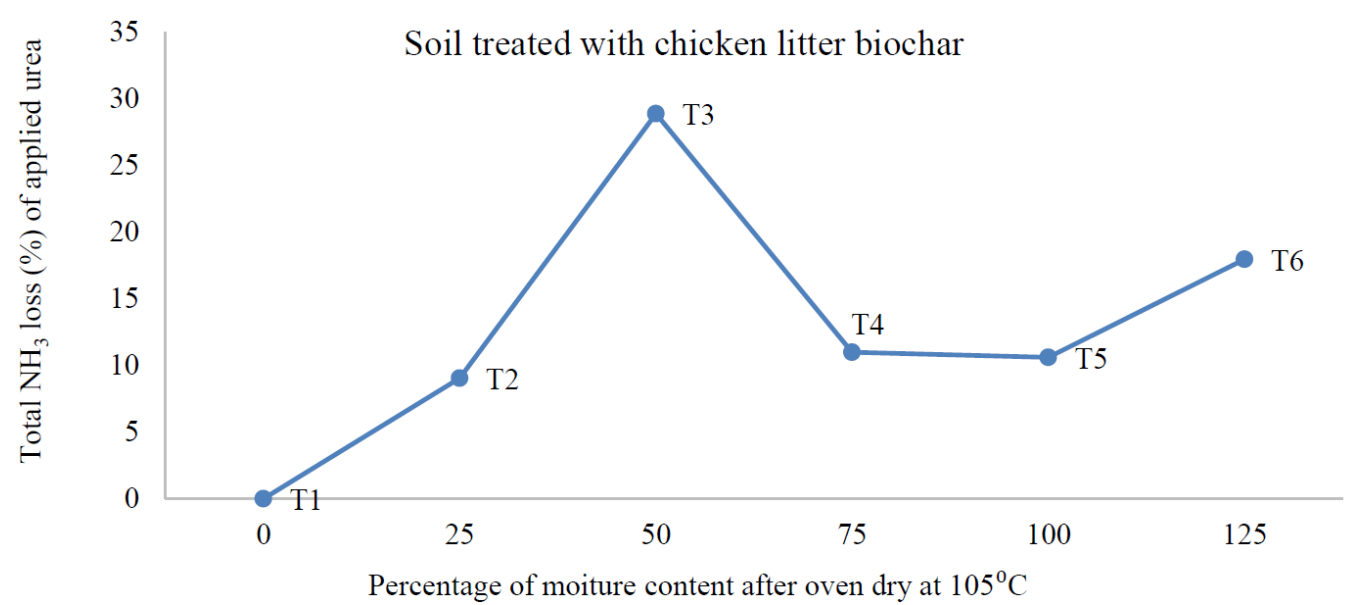

Figure 4. Soil water levels on total ammonia volatilization

\subsection{Water Levels on Ammonia Volatilization from Soils without Chicken Litter Biochar}

There was no ammonia volatilization from $\mathrm{T} 7$ because of the absence of soil water to hydrolyze urea (Palanivell 
et al., 2016) and this finding is also consistent with that of T1 (Figure 2). This indicates that, with or without organic amendments, soil without water will not cause ammonia volatilization. At $25 \%$ soil water (T8), urea hydrolysis caused ammonia loss and this finding is consistent with that of soil with chicken litter biochar (T2) (Figures 5, 6, and 7). Furthermore, 50\% soil water (T9) cause higher loss of ammonia (Figure 6). This observation also corroborates with that of T3 (soil with chicken litter biochar and 50\% soil water) (Figure 3). As soil water increased to $75 \%$ (T10), ammonia loss significantly decreased because of nitrification of ammonium to nitrate, thus resulting in decrease of $\mathrm{NH}_{4}{ }^{+}$concentration in the soil solution. As soil water increased to $100 \%$ field capacity (T11), ammonia loss increased because all the soil pores were field with water and this prevented biological oxidation of $\mathrm{NH}_{4}^{+}$to nitrate. However, at $125 \%$ soil water (T12), ammonia loss decreased. Total ammonia loss after 41 days of this study showed that, the emission of ammonia from T9 was similar to that of T11 but significantly higher than those of T7, T8, T10, and T12 (Figure 6). The highest ammonia volatilization from soil without chicken litter biochar occurred at 50\% soil water (Figure 7). This result is similar to that of T3 (soil with chicken litter biochar) (Figure 3).

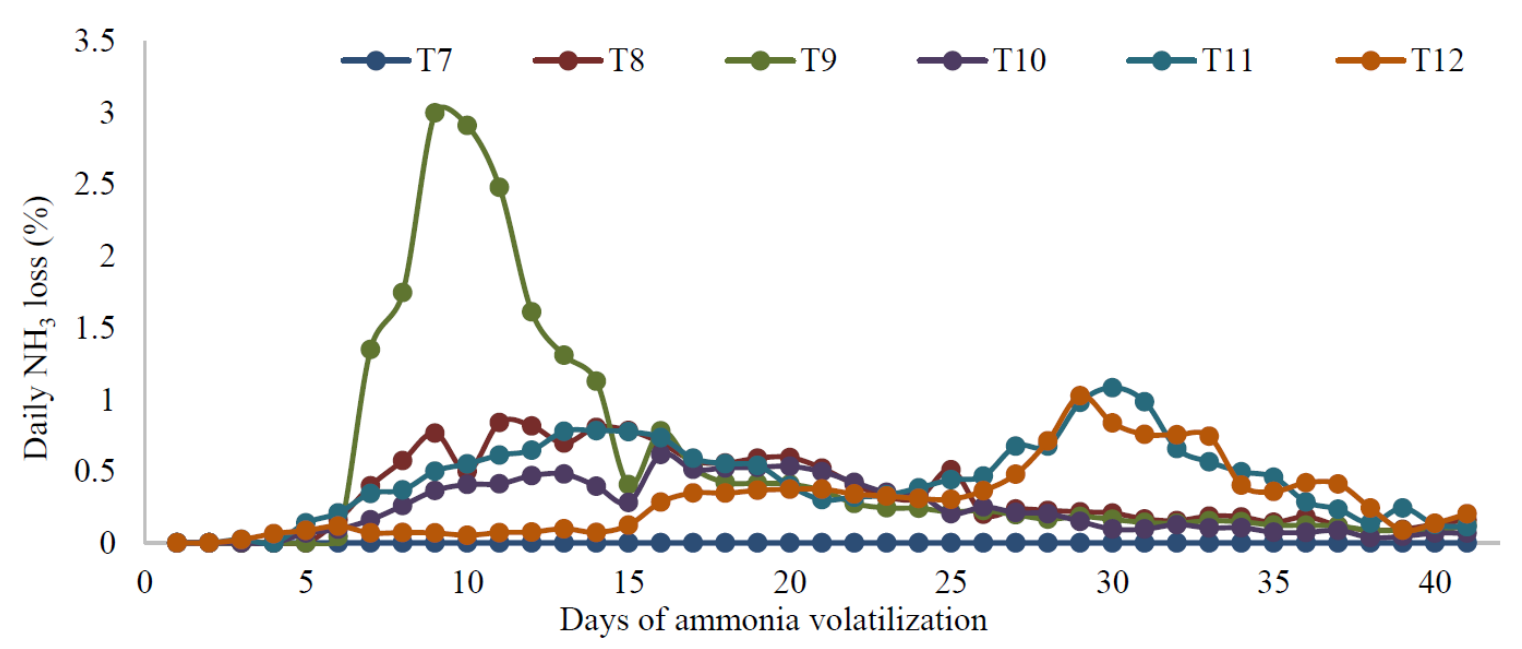

Figure 5. Soil water contents on daily ammonia volatilization from soil without chicken litter biochar.

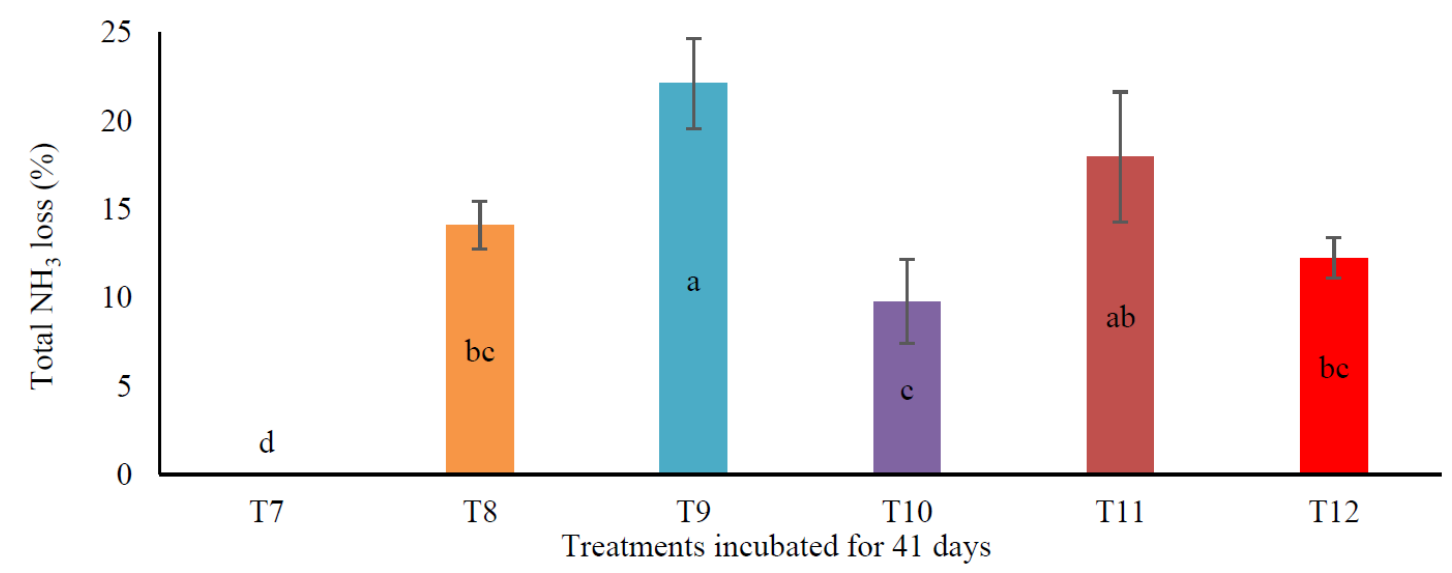

Figure 6. Water contents on total ammonia volatilization from soil without chicken litter biochar 


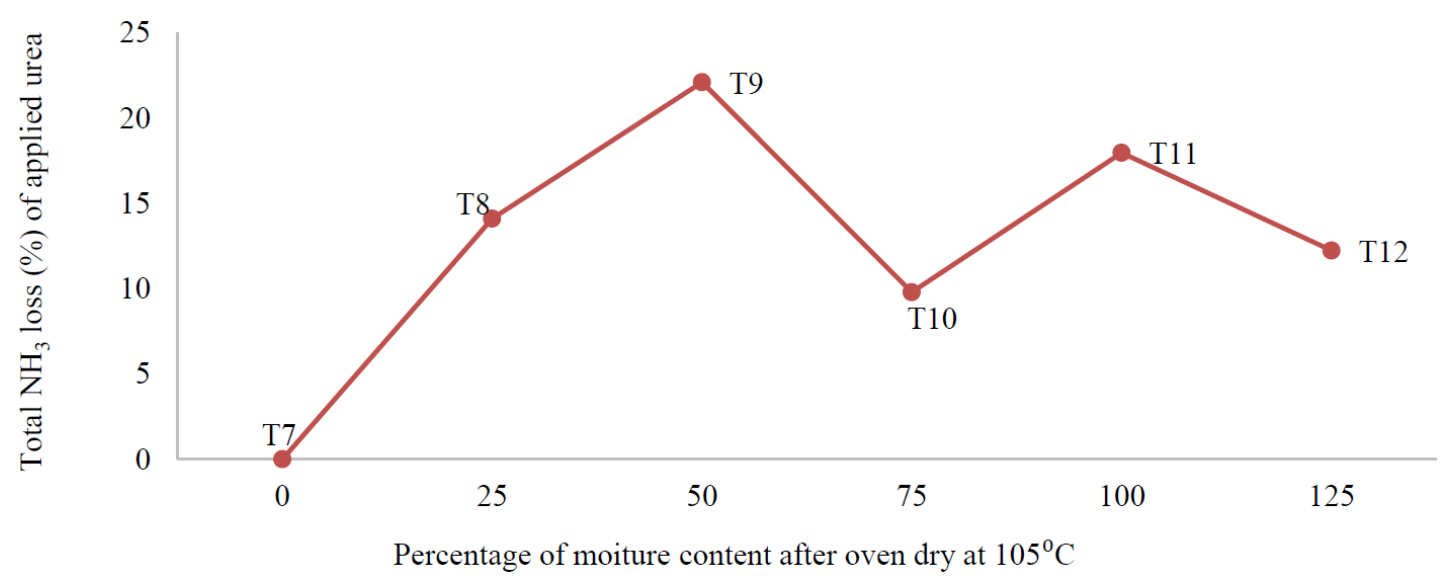

Figure 7. Soil water contents on total ammonia volatilization

\subsection{Water Content on Ammonia Volatilization from Soils with and Without Chicken Litter Biochar}

The fact that there were no ammonia emissions from T1 (Soil + biochar + urea + no soil water) and T7 (Soil + urea + no soil water) (Figures 8,9 , and 10) soils suggest that without soil water, there will be no ammonia volatilization regardless of the presence of chicken litter biochar and urea. However, when the soils of T2 and T8 were moistened with water to $25 \%$ field capacity, ammonia volatilization occurred although the amounts emitted were similar they were lower than those of T3 and T9 (Figure 9). These results confirm that of Al-Kanani et al. (1991) who reported that, at low soil water, both urea hydrolysis and ammonia volatilization are slow. The chicken litter biochar did not significantly reduce ammonia loss compared with soil without chicken litter biochar (Figure 9).

Results in Figure 9 show that the total ammonia loss from T3 was similar to that of T9 but significantly higher than those of T1, T2, T4, T5, T6, T7, T8, T10, T11, and T12. Also, the total ammonia loss from T9 was similar to that of T6, T8, and T10 but significantly higher than those of T1, T2, T4, T5, T7, T11, and T12 (Figure 9). Soil water affected $\mathrm{NH}_{4}{ }^{+}$concentrations in the soil solution and at $50 \%$ soil water, the concentration of $\mathrm{NH}_{4}^{+}$was high thus, resulting in higher ammonia losses (Cameron et al., 2013). Increasing soil water increases rates of urea hydrolysis and ammonia production from urea (Cameron et al., 2013). Seventy-five percent soil water and above resulted in lower ammonia losses because there was significant amount of water to dilute the concentrations of $\mathrm{NH}_{4}{ }^{+}$in soil solution (Cameron et al., 2013). As shown in Figure 10, chicken litter biochar as soil amendment only minimized ammonia volatilization at $1 \%$ to $32 \%$ and $80 \%$ to $115 \%$ field capacity due to higher sorption of ammonia onto the surfaces of the chicken litter biochar (Asada et al., 2002; Clough and Condron, 2010). This further indicates that sorption of ammonia by chicken litter biochar (Jia et al., 2015) is lower at 33\% to 79\% and above $116 \%$ field capacity.

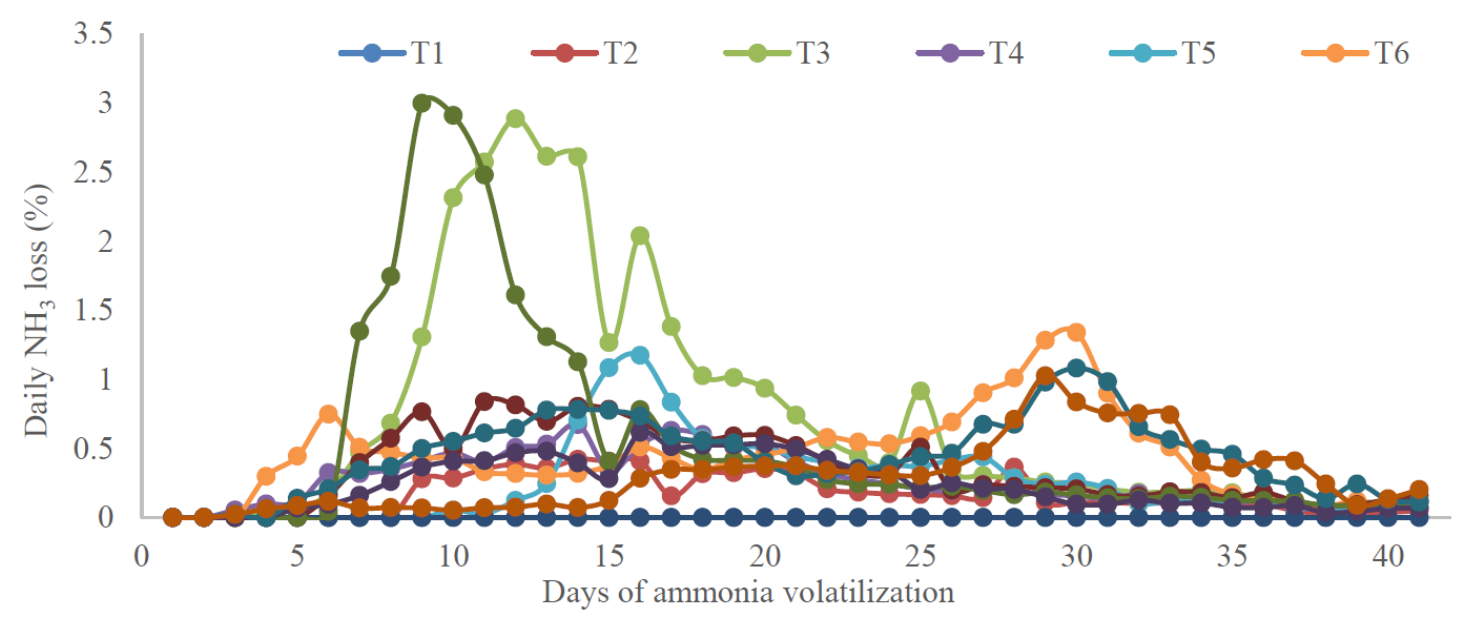

Figure 8. Water levels on daily ammonia volatilization from soils with and without chicken litter biochar 


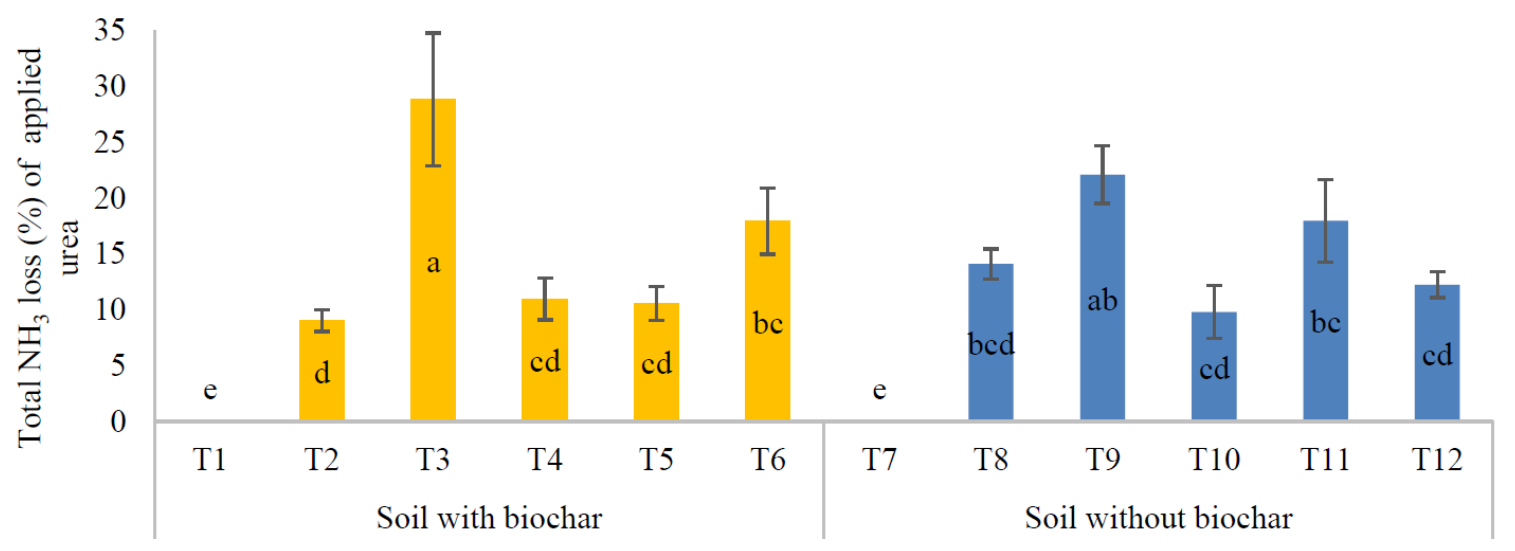

Treatments incubated for 41 days

Figure 9. Water levels on total ammonia volatilization from soils with and without chicken litter biochar

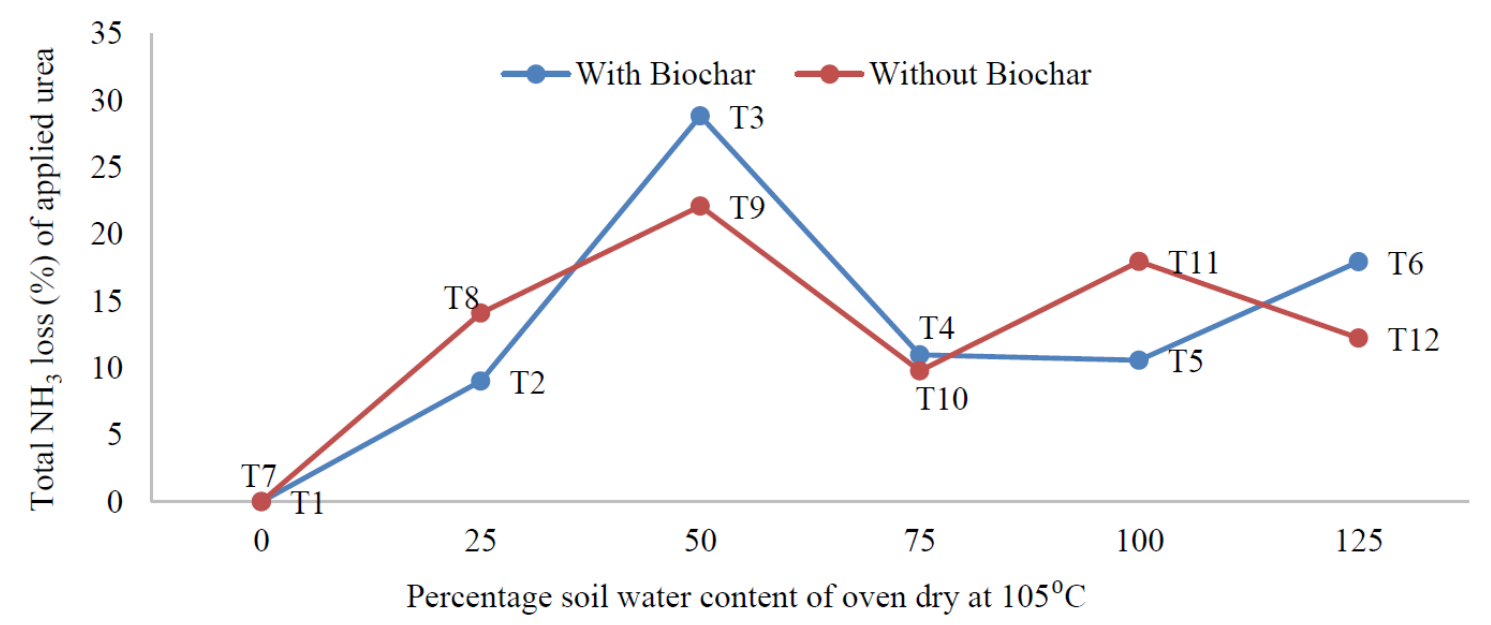

Figure 10. Soil water content on total ammonia volatilization

\subsection{Water Levels on Selected Chemical Properties of Soils with Chicken Litter Biochar}

Soil $\mathrm{pH}$ in water and $\mathrm{KCl}$ of T3, T4, T5, and T6 were not significantly different but higher than those of $\mathrm{T} 1$ and $\mathrm{T} 2$ (Table 4). The soil pH of T2 was higher than that of T1 (Table 4). Although soils with T1, T2, T3, T4, T5, and $\mathrm{T} 6$ were amended with the same amount of chicken litter biochar, the $\mathrm{pH}$ of $\mathrm{T} 1$ was significantly lower $\mathrm{pH}$ because $\mathrm{T} 1$ soil had no soil water to initiate urea hydrolysis $\left(\mathrm{NH}_{3}+\mathrm{H}_{2} \mathrm{O}+\mathrm{CO}_{2} \rightarrow \mathrm{NH}_{4}{ }^{+}+\mathrm{CO}_{2}+\mathrm{OH}^{-}\right)$ (Palanivell et al., 2017; Sommer et al., 2004). This further explains why in T1, ammonia was not released throughout the incubation study. In T2, the soil $\mathrm{pH}$ was higher than that of T1 because soil water at $25 \%$ enabled some of the urea to hydrolyze (Sommer et al., 2004) to produce some $\mathrm{OH}^{-}$to increase the soil $\mathrm{pH}$. Soil $\mathrm{pH}$ of T3 was similar to those of T4, T5, and $\mathrm{T} 6$ because the soil water with $\mathrm{T} 3, \mathrm{~T} 4, \mathrm{~T} 5$, and $\mathrm{T} 6$ were enough to hydrolyze most of urea to produce similar amount of $\mathrm{OH}^{-}$. The soil total acidity and exchangeable $\mathrm{H}^{+}$of $\mathrm{T} 1$ were lower than those of T2, T3, T4, T5, and T6 but exchangeable $\mathrm{Al}^{3+}$ was negligible in T2, T3, T4, T5, and T6 (Table 4). The soil total $\mathrm{C}$ of $\mathrm{T} 1$ was not different from those of $\mathrm{T} 3$ and $\mathrm{T} 6$ but significantly higher than those of $\mathrm{T} 2$, $\mathrm{T} 4$, and $\mathrm{T} 5$. Soil CEC of T1 was significantly higher than that of T6 (Table 4) due to absence of water in T1 and chicken litter biochar was only activated when the soil samples were solubilized for analysis. This indicates that for biochars to be active in soils, they need soil water to reduce $\mathrm{Al}^{3+}$ in soil solution.

Exchangeable $\mathrm{NH}_{4}{ }^{+}$of $\mathrm{T} 4, \mathrm{~T} 5$, and $\mathrm{T} 6$ were not different but higher than those of T3, T2, and T1 (Table 5) because the ammonium ions increased with increasing soil water (Table 5). Available $\mathrm{NO}_{3}^{-}$of T5 was significantly higher than those of T1, T2, T3, T4, and T6 (Table 5). Soil water did not affect total P, total N, exchangeable $\mathrm{Na}$, and $\mathrm{Cu}$ availability (Tables 4 and 5). Soil total $\mathrm{K}$ of $\mathrm{T} 1$ and $\mathrm{T} 2$ were not different but higher than those of T3, T4, T5, and T6. Exchangeable K of T4, T5, and T6 were lower because of $\mathrm{K}$ dissolution in the 
soil. Generally, the soil exchangeable cations of T1 were higher compared with those of T2, T3, T4, T5, and T6 (treatments with soil water) because of no water.

Table 4. Water levels on selected chemical properties of soil with chicken litter biochar

\begin{tabular}{|c|c|c|c|c|c|c|c|c|c|}
\hline Treatments & $\mathrm{pH}$ in $\mathrm{KCl}$ & $\mathrm{pH}$ in water & Total C & CEC & Total acidity & $\begin{array}{l}\text { Exchangeable } \\
\mathbf{A l}^{3+}\end{array}$ & $\begin{array}{l}\text { Exchangeable } \\
\mathrm{H}^{+} \\
\end{array}$ & $\begin{array}{l}\text { Exchangeable } \\
\text { K }\end{array}$ & Total P \\
\hline & & & $\%$ & \multicolumn{4}{|c|}{ 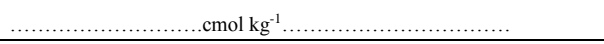 } & \multicolumn{2}{|c|}{$\mathrm{mg} \mathrm{kg}^{-1}$} \\
\hline $\mathrm{T} 1$ & $3.8 \mathrm{c} \pm 0.11$ & $5.98 c \pm 0.04$ & $4.45 \mathrm{a} \pm 0.19$ & $6.03 a \pm 0.3$ & $0.2 b \pm 0.01$ & $0.06 \mathrm{a} \pm 0.01$ & $0.14 \mathrm{~b} \pm 0.01$ & $2.2 \mathrm{a} \pm 0.11$ & $0.12 \mathrm{a} \pm 0.09$ \\
\hline $\mathrm{T} 2$ & $4.66 b \pm 0.15$ & $6.48 \mathrm{~b} \pm 0.02$ & $2.36 \mathrm{~d} \pm 0.04$ & $5.03 \mathrm{ab} \pm 0.43$ & $0.38 \mathrm{a} \pm 0.05$ & 0 & $0.38 a \pm 0.05$ & $1.83 a \pm 0.09$ & $0.39 a \pm 0.03$ \\
\hline $\mathrm{T} 3$ & $5.22 \mathrm{a} \pm 0.06$ & $6.46 \mathrm{~b} \pm 0.11$ & $3.56 \mathrm{abc} \pm 0.08$ & $4.63 \mathrm{ab} \pm 0.58$ & $0.33 \mathrm{ab} \pm 0.04$ & 0 & $0.33 \mathrm{a} \pm 0.04$ & $1.42 \mathrm{~b} \pm 0.09$ & $0.49 a \pm 0.16$ \\
\hline $\mathrm{T} 4$ & $5.5 \mathrm{a} \pm 0.16$ & $6.86 \mathrm{a} \pm 0.01$ & $2.59 \mathrm{~cd} \pm 0.14$ & $5.97 \mathrm{a} \pm 0.33$ & $0.42 \mathrm{a} \pm 0.01$ & 0 & $0.42 \mathrm{a} \pm 0.01$ & $1.21 \mathrm{~b} \pm 0.06$ & $0.25 \mathrm{a} \pm 0.1$ \\
\hline T5 & $5.65 \mathrm{a} \pm 0.02$ & $7.04 a \pm 0.02$ & $2.71 \mathrm{bcd} \pm 0.39$ & $4.53 \mathrm{ab} \pm 0.3$ & $0.37 \mathrm{a} \pm 0.02$ & 0 & $0.37 \mathrm{a} \pm 0.02$ & $1.21 \mathrm{~b} \pm 0.05$ & $0.099 \mathrm{a} \pm 0.07$ \\
\hline T6 & $5.67 \mathrm{a} \pm 0.01$ & $6.95 \mathrm{a} \pm 0.003$ & $3.87 \mathrm{ab} \pm 0.39$ & $3.73 b \pm 0.47$ & $0.42 \mathrm{a} \pm 0.02$ & 0 & $0.42 \mathrm{a} \pm 0.02$ & $1.07 \mathrm{~b} \pm 0.04$ & $0.115 \mathrm{a} \pm 0.098$ \\
\hline
\end{tabular}

Note: Different letter within a row indicate significant difference between the means of three replicates \pm standard error using Turkey's test at $p \leq 0.05$.

Table 5. Water levels on selected chemical properties of soil with chicken litter biochar

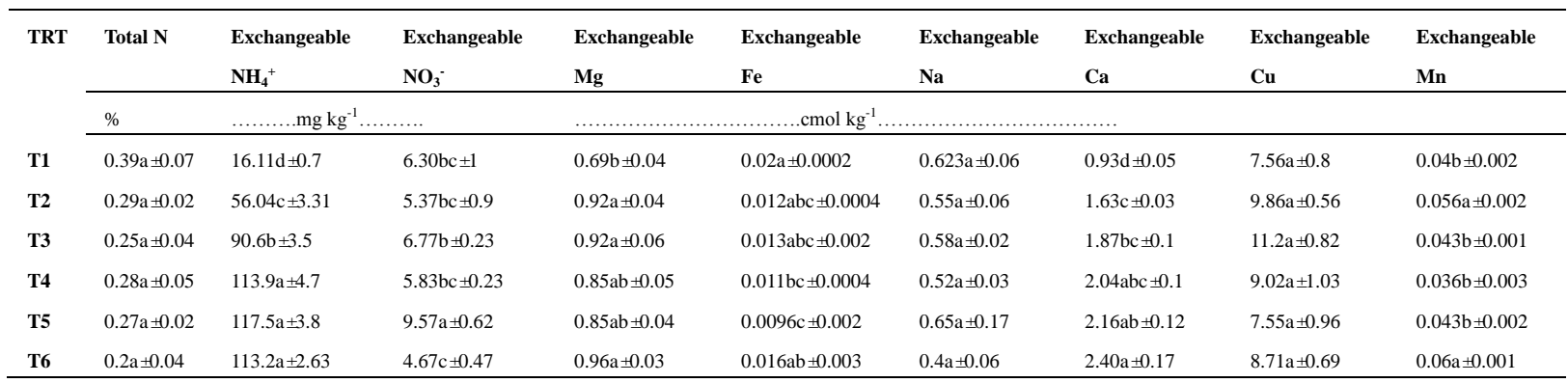

Note: Different letter within a row indicate significant difference between the means of three replicates \pm standard error using Turkey's test at $p \leq 0.05$.

\subsection{Water Levels on Selected Chemical Properties of Soils without Chicken Litter Biochar}

$\mathrm{pH}$ in water and $\mathrm{KCl}$ of soil without chicken litter biochar increased with increasing soil water. The highest soil $\mathrm{pH}$ occurred in T11 and T12 (Table 6) because of their higher soil water which effectively hydrolyzed urea to produce $\mathrm{OH}^{-}(\mathrm{Xu}$ et al. 2006). This explains why soil $\mathrm{pH}$ increases with urea hydrolysis. Total acidity and exchangeable $\mathrm{Al}^{3+}$ of $\mathrm{T} 7$ were higher than those of $\mathrm{T} 8, \mathrm{~T} 9, \mathrm{~T} 10, \mathrm{~T} 11$, and $\mathrm{T} 12$ (Table 6), suggesting that soil water plays an important role in controlling soil acidity (Cheng et al., 2008). The total soil acidity and $\mathrm{Al}^{3+}$ of $\mathrm{T} 7$ were higher than those of $\mathrm{T} 9, \mathrm{~T} 10, \mathrm{~T} 11$, and $\mathrm{T} 12$ because there was no urea hydrolysis in $\mathrm{T} 7$. These observations demonstrates that urea hydrolysis can minimize soil exchangeable $\mathrm{Al}^{3+}$ (Table 6). The findings also suggest that the affinity of ammonia for $\mathrm{H}^{+}$produced during $\mathrm{Al}$ and $\mathrm{Fe}$ hydrolysis is higher than $\mathrm{H}^{+}$from water molecules. The exchangeable $\mathrm{H}^{+}$of $\mathrm{T} 9, \mathrm{~T} 10, \mathrm{~T} 11$, and $\mathrm{T} 12$ were not different but significantly higher than those of $\mathrm{T} 2$ and $\mathrm{T} 1$ (Table 6). Exchangeable $\mathrm{NH}_{4}{ }^{+}$of $\mathrm{T} 11$ and $\mathrm{T} 10$ were not different from those of T8, T9, T10, and $\mathrm{T} 12$ but significantly higher than that of T7 (Table 7) however, this ion increased with increasing soil water (Table 7).

The available $\mathrm{NO}_{3}{ }^{-}$of $\mathrm{T} 8$ and $\mathrm{T} 9$ were similar but higher than those of $\mathrm{T} 7, \mathrm{~T} 10, \mathrm{~T} 11$, and T12 (Table 7). Total C of T11 was not significantly different from those of T7, 9, and T12 but higher than that of T8. Soil CEC of T7 was significantly higher than those of T11 and T12 (Table 5). However, soil total K, P, and N, and soil exchangeable Mg, Na, and $\mathrm{Cu}$ of T7, T8, T9, T10, T11, and T12 were similar (Tables 6 and 7). These results were similar to those of the soils with chicken litter biochar thus, indicating that, variations among treatments were due to the differences in soil water as the soil water affected the chemical reactions of the treatments with soil. 
Table 6. Water levels on selected chemical properties of soil without chicken litter biochar.

\begin{tabular}{|c|c|c|c|c|c|c|c|c|c|}
\hline TRT & $\mathrm{pH}$ in $\mathrm{KCl}$ & $\mathrm{pH}$ in water & Total C & CEC & Total acidity & $\begin{array}{l}\text { Exchangeable } \\
\mathbf{A l}^{3+} \\
\end{array}$ & $\begin{array}{l}\text { Exchangeable } \\
\mathbf{H}^{+} \\
\end{array}$ & $\begin{array}{l}\text { Exchangeable } \\
\mathbf{K}\end{array}$ & Total P \\
\hline & & & \multicolumn{6}{|c|}{ (n) } & $\ldots \mathrm{mg} \mathrm{kg}^{-1} \ldots$ \\
\hline T7 & $3.62 \mathrm{~d} \pm 0.02$ & $4.54 \mathrm{~d} \pm 0.09$ & $2.32 \mathrm{ab} \pm 1$ & $6.9 \mathrm{a} \pm 0.42$ & $1.17 \mathrm{a} \pm 0.01$ & $0.86 a \pm 0.02$ & $0.3 c \pm 0.03$ & $0.62 \mathrm{ab} \pm 0.04$ & $0.045 \mathrm{a} \pm 0.04$ \\
\hline T8 & $4.21 \mathrm{c} \pm 0.02$ & $6.04 \mathrm{c} \pm 0.04$ & $3.09 \mathrm{~b} \pm 0.39$ & $6.17 \mathrm{ab} \pm 0.19$ & $0.57 \mathrm{~b} \pm 0.03$ & $0.22 b \pm 0.01$ & $0.35 b c \pm 0.02$ & $0.58 b \pm 0.03$ & $0.073 a \pm 0.05$ \\
\hline T9 & $4.40 \mathrm{c} \pm 0.09$ & $6.27 b c \pm 0.07$ & $2.32 \mathrm{ab} \pm 1$ & $6.73 \mathrm{ab} \pm 0.54$ & $0.53 b \pm 0.03$ & 0 & $0.53 a \pm 0.03$ & $0.73 \mathrm{ab} \pm 0.01$ & $0.09 \mathrm{a} \pm 0.05$ \\
\hline T10 & $4.75 b \pm 0.02$ & $6.56 \mathrm{ab} \pm 0.07$ & $1.55 b \pm 0.39$ & $7.03 a \pm 0.44$ & $0.46 \mathrm{~b} \pm 0.04$ & 0 & $0.46 \mathrm{ab} \pm 0.04$ & $0.71 \mathrm{ab} \pm 0.07$ & $0.16 \mathrm{a} \pm 0.06$ \\
\hline T11 & $4.84 \mathrm{ab} \pm 0.05$ & $6.61 \mathrm{a} \pm 0.06$ & $3.09 a \pm 0.39$ & $4.27 \mathrm{~b} \pm 0.64$ & $0.48 b \pm 0.01$ & 0 & $0.48 a \pm 0.01$ & $0.73 \mathrm{ab} \pm 0.03$ & $0.041 \mathrm{a} \pm 0.04$ \\
\hline T12 & $5.05 \mathrm{a} \pm 0.03$ & $6.83 a \pm 0.09$ & $2.36 \mathrm{ab} \pm 0.04$ & $4.37 \mathrm{~b} \pm 0.48$ & $0.47 \mathrm{~b} \pm 0.03$ & 0 & $0.47 \mathrm{a} \pm 0.03$ & $0.82 \mathrm{a} \pm 0.03$ & $0.12 \mathrm{a} \pm 0.07$ \\
\hline
\end{tabular}

Note: Different letter within a row indicate significant difference between the means of three replicates \pm standard error using Turkey's test at $p \leq 0.05$.

Table 7. Water levels on selected chemical properties of soil without chicken litter biochar.

\begin{tabular}{|c|c|c|c|c|c|c|c|c|c|}
\hline TRT & Total N & $\begin{array}{l}\text { Exchangeable } \\
\mathrm{NH}_{4}{ }^{+}\end{array}$ & $\begin{array}{l}\text { Exchangeable } \\
\mathrm{NO}_{3}{ }^{-} \\
\end{array}$ & $\begin{array}{l}\text { Exchangeable } \\
\mathrm{Mg}\end{array}$ & $\begin{array}{l}\text { Exchangeable } \\
\mathrm{Fe}\end{array}$ & $\begin{array}{l}\text { Exchangeable } \\
\mathrm{Na}\end{array}$ & $\begin{array}{l}\text { Exchangeable } \\
\text { Ca }\end{array}$ & $\begin{array}{l}\text { Exchangeable } \\
\mathrm{Cu}\end{array}$ & $\begin{array}{l}\text { Exchangeable } \\
\text { Mn }\end{array}$ \\
\hline & $\%$ & ..........mg kg-1. & & & & Cmol kg ${ }^{-1}$. & & & \\
\hline $\mathbf{T} 7$ & $0.23 \mathrm{a} \pm 0.01$ & $8.87 \mathrm{~b} \pm 1.68$ & $6.07 \mathrm{bc} \pm 0.47$ & $0.39 \mathrm{a} \pm 0.005$ & $0.08 \mathrm{a} \pm 0.004$ & $0.26 \mathrm{a} \pm 0.02$ & $1.6 \mathrm{~b} \pm 0.08$ & $8.71 \mathrm{a} \pm 0.56$ & $0.053 a \pm 0.001$ \\
\hline T8 & $0.16 \mathrm{a} \pm 0.03$ & $41.1 \mathrm{ab} \pm 13.1$ & $25.69 a \pm 2.23$ & $0.41 \mathrm{a} \pm 0.02$ & $0.015 b c \pm 0.002$ & $0.23 a \pm 0.03$ & $1.7 \mathrm{~b} \pm 0.11$ & $9.13 a \pm 0.96$ & $0.042 \mathrm{abc} \pm 0.003$ \\
\hline T9 & $0.11 \mathrm{a} \pm 0.03$ & $50.2 \mathrm{ab} \pm 19.1$ & $21.25 \mathrm{a} \pm 1.17$ & $0.39 \mathrm{a} \pm 0.02$ & $0.01 c \pm 0.0005$ & $0.24 a \pm 0.01$ & $1.67 \mathrm{~b} \pm 0.03$ & $10.39 a \pm 0.36$ & $0.04 c \pm 0.002$ \\
\hline T10 & $0.10 \mathrm{a} \pm 0.02$ & $83.6 \mathrm{a} \pm 15.1$ & $12.61 \mathrm{~b} \pm 2.02$ & $0.36 \mathrm{a} \pm 0.005$ & $0.01 \mathrm{c} \pm 0.0005$ & $0.18 \mathrm{a} \pm 0.01$ & $1.78 \mathrm{ab} \pm 0.01$ & $8.60 \mathrm{a} \pm 0.46$ & $0.04 \mathrm{bc} \pm 0.003$ \\
\hline T11 & $0.14 \mathrm{a} \pm 1$ & $96.9 \mathrm{a} \pm 16.77$ & $5.18 \mathrm{c} \pm 0.66$ & $0.37 \mathrm{a} \pm 0.03$ & $0.009 \mathrm{c} \pm 0.0004$ & $0.23 a \pm 0.001$ & $1.79 \mathrm{ab} \pm 0.05$ & $9.76 \mathrm{a} \pm 0.66$ & $0.043 \mathrm{abc} \pm 0.002$ \\
\hline T12 & $0.18 \mathrm{a} \pm 0.06$ & $64.91 \mathrm{ab} \pm 17.8$ & $10.74 b c \pm 0.23$ & $0.4 \mathrm{a} \pm 0.007$ & $0.02 \mathrm{~b} \pm 0.001$ & $0.25 \mathrm{a} \pm 0.02$ & $2.01 \mathrm{a} \pm 0.02$ & $8.4 \mathrm{a} \pm 0.56$ & $0.052 \mathrm{ab} \pm 0.002$ \\
\hline
\end{tabular}

Note: Different letter within a row indicate significant difference between the means of three replicates \pm standard error using Turkey's test at $p \leq 0.05$.

\subsection{Water Levels on Selected Chemical Properties of Soils with and Without Chicken Litter Biochar}

Generally, the $\mathrm{pH}$ in water and $\mathrm{KCl}$ were higher in the soils with chicken litter biochar than those without this amendment (Table 8) because of the liming effect of the chicken litter biochar (Xu et al., 2006). The carboxylic- $\mathrm{COOH}$ and phenolic-OH groups of the chicken litter biochar further increased the concentration of $\mathrm{OH}^{-}$in soil solution besides those which were produced during urea hydrolysis (Xu et al., 2006). Total acidity, exchangeable $\mathrm{Al}^{3+}, \mathrm{H}^{+}, \mathrm{NH}_{4}{ }^{+}$, and $\mathrm{Ca}$ increased with increasing soil water in the soils with and without chicken litter biochar (Tables 8 and 9) because chicken litter biochar has the ability to reduce soil exchangeable acidity (Van Zwieten et al., 2009) due to its higher carboxylic and phenolic contents. These functional groups have higher affinity for $\mathrm{Al}^{3+}$ and $\mathrm{Fe}^{3+}$. Although $\mathrm{Al}^{3+}$ can be minimized during urea hydrolysis, the addition of chicken litter biochar is responsible for the further decrease in soil acid (Van Zwieten et al., 2009).

Total C of T1 was significantly higher than those of T2, T4, T5, T7, T8, T9, T10, T11, and T12 (Table 8). Soils with chicken litter biochar showed higher soil carbon than the soils without chicken litter biochar because of recalcitrant carbon content of chicken litter biochar (Gaskin et al., 2008; Lehmann, 2007; Rebecca, 2007). Soil total $\mathrm{P}$, exchangeable $\mathrm{NH}_{4}{ }^{+}, \mathrm{Ca}, \mathrm{Cu}$, and $\mathrm{Mn}$ did not increase significantly in the soils with chicken litter biochar compared with the soils without chicken litter biochar (Table 9). However, exchangeable $\mathrm{K}, \mathrm{Mg}$, and $\mathrm{Na}$ were generally increased in the soils with chicken litter biochar (Tables 8 and 9) whereas available $\mathrm{NO}_{3}{ }^{-}$and exchangeable $\mathrm{Fe}$ were significantly higher in the soils without chicken litter biochar than those with chicken litter biochar (Table 9). These differences were because the complex and heterogeneous chemical composition of chicken litter biochar increased the soil's chemical properties. Functional groups such as hydroxyl -OH, amino- $\mathrm{NH}_{2}$, ketone $-\mathrm{OR}$, ester $-(\mathrm{C}=\mathrm{O}) \mathrm{OR}$, nitro $-\mathrm{NO}_{2}$, aldehyde $-(\mathrm{C}=\mathrm{O}) \mathrm{H}$, carboxyl $-(\mathrm{C}=\mathrm{O}) \mathrm{OH}$ on the outer surface of the graphene sheets of chicken litter biochar (Harris, 1997; Harris and Tsang, 1997) enabled this organic amendment to act as electron donor and electron acceptor (Amonette \& Joseph, 2009) to improve soil chemical properties. 
Table 8. Water levels on selected chemical properties of soil with and without biochar

\begin{tabular}{|c|c|c|c|c|c|c|c|c|c|}
\hline Treatments & $\mathrm{pH}$ in $\mathrm{KCl}$ & pH in water & Total C & CEC & $\begin{array}{l}\text { Exchangeable } \\
\text { acidity }\end{array}$ & $\begin{array}{l}\text { Exchangeable } \\
\mathrm{Al}^{3+}\end{array}$ & $\begin{array}{l}\text { Exchangeable } \\
\mathrm{H}^{+}\end{array}$ & $\begin{array}{l}\text { Exchangeable } \\
\text { K }\end{array}$ & Total P \\
\hline & & & $\%$ & \multicolumn{4}{|c|}{. } & \multicolumn{2}{|c|}{$\ldots . . . \mathrm{mg} \mathrm{kg}^{-1} \ldots .}$. \\
\hline T1 & $3.8 \mathrm{~g} \pm 0.11$ & $5.98 \mathrm{~g} \pm 0.04$ & $4.45 \mathrm{a} \pm 0.19$ & $6.03 \mathrm{abcde} \pm 0.3$ & $0.2 \mathrm{f} \pm 0.01$ & $0.06 \mathrm{c} \pm 0.01$ & $0.14 \mathrm{e} \pm 0.01$ & $2.2 \mathrm{a} \pm 0.11$ & $0.12 \mathrm{ab} \pm 0.09$ \\
\hline $\mathbf{T 2}$ & $4.66 \mathrm{de} \pm 0.15$ & $6.48 \mathrm{de} \pm 0.02$ & $2.36 \mathrm{~cd} \pm 0.04$ & $5.03 \mathrm{abcde} \pm 0.43$ & $0.38 \mathrm{de} \pm 0.05$ & 0 & $0.38 \mathrm{bcd} \pm 0.05$ & $1.83 \mathrm{~b} \pm 0.09$ & $0.39 \mathrm{ab} \pm 0.03$ \\
\hline T3 & $5.22 \mathrm{bc} \pm 0.06$ & $6.46 \mathrm{de} \pm 0.11$ & $3.56 \mathrm{abc} \pm 0.08$ & $4.63 \mathrm{bcde} \pm 0.58$ & $0.33 \mathrm{ef} \pm 0.04$ & 0 & $0.33 \mathrm{~d} \pm 0.04$ & $1.42 \mathrm{c} \pm 0.09$ & $0.49 \mathrm{a} \pm 0.16$ \\
\hline T4 & $5.5 \mathrm{ab} \pm 0.16$ & $6.86 \mathrm{a} \pm 0.01$ & $2.59 \mathrm{bcd} \pm 0.14$ & 5.97 abcde \pm 0.33 & $0.42 \mathrm{cde} \pm 0.01$ & 0 & $0.42 \mathrm{abcd} \pm 0.01$ & $1.21 \mathrm{~cd} \pm 0.06$ & $0.25 \mathrm{ab} \pm 0.1$ \\
\hline T5 & $5.65 \mathrm{a} \pm 0.02$ & $7.04 a \pm 0.02$ & $2.71 \mathrm{bcd} \pm 0.39$ & $4.53 \mathrm{bcde} \pm 0.3$ & $0.37 \mathrm{de} \pm 0.02$ & 0 & $0.37 b c d \pm 0.02$ & $1.21 \mathrm{~cd} \pm 0.05$ & $0.099 \mathrm{ab} \pm 0.07$ \\
\hline T6 & $5.67 \mathrm{a} \pm 0.01$ & $6.95 \mathrm{a} \pm 0.003$ & $3.87 \mathrm{ab} \pm 0.39$ & $3.73 \mathrm{e} \pm 0.47$ & $0.42 \mathrm{cde} \pm 0.02$ & 0 & $0.42 \mathrm{abcd} \pm 0.02$ & $1.07 \mathrm{de} \pm 0.04$ & $0.115 \mathrm{ab} \pm 0.098$ \\
\hline $\mathbf{T 7}$ & $3.62 g \pm 0.02$ & $4.54 \mathrm{~h} \pm 0.09$ & $2.32 \mathrm{~cd} \pm 1$ & $6.9 \mathrm{ab} \pm 0.42$ & $1.17 \mathrm{a} \pm 0.01$ & $0.86 \mathrm{a} \pm 0.02$ & $0.3 \mathrm{~d} \pm 0.03$ & $0.62 \mathrm{f} \pm 0.04$ & $0.045 b \pm 0.04$ \\
\hline T8 & $4.21 \mathrm{f} \pm 0.02$ & $6.04 \mathrm{fg} \pm 0.04$ & $3.09 b c \pm 0.39$ & $6.17 \mathrm{abcd} \pm 0.19$ & $0.57 b \pm 0.03$ & $0.22 b \pm 0.01$ & $0.35 \mathrm{bcd} \pm 0.02$ & $0.58 \mathrm{f} \pm 0.03$ & $0.066 \mathrm{ab} \pm 0.05$ \\
\hline T9 & $4.40 \mathrm{ef} \pm 0.09$ & $6.27 \mathrm{ef} \pm 0.07$ & $2.32 \mathrm{~cd} \pm 1$ & $6.73 \mathrm{abc} \pm 0.54$ & $0.53 b c \pm 0.03$ & 0 & $0.53 a \pm 0.03$ & $0.73 \mathrm{f} \pm 0.01$ & $0.09 \mathrm{ab} \pm 0.05$ \\
\hline T10 & $4.75 \mathrm{de} \pm 0.02$ & $6.56 \mathrm{~cd} \pm 0.07$ & $1.55 \mathrm{~d} \pm 0.39$ & $7.03 a \pm 0.44$ & $0.46 \mathrm{bcde} \pm 0.04$ & 0 & $0.46 \mathrm{abc} \pm 0.04$ & $0.71 \mathrm{f} \pm 0.07$ & $0.16 \mathrm{ab} \pm 0.06$ \\
\hline T11 & $4.84 \mathrm{~cd} \pm 0.05$ & $6.61 \mathrm{bcd} \pm 0.06$ & $3.09 b c \pm 0.39$ & $4.27 \mathrm{de} \pm 0.64$ & $0.48 \mathrm{bcd} \pm 0.01$ & 0 & $0.48 \mathrm{ab} \pm 0.01$ & $0.73 f \pm 0.03$ & $0.041 b \pm 0.04$ \\
\hline T12 & $5.05 \mathrm{~cd} \pm 0.03$ & $6.83 \mathrm{abc} \pm 0.09$ & $2.36 \mathrm{~cd} \pm 0.04$ & $4.37 \mathrm{cde} \pm 0.48$ & $0.47 \mathrm{bcd} \pm 0.03$ & 0 & $0.47 \mathrm{ab} \pm 0.03$ & $0.82 \mathrm{ef} \pm 0.03$ & $0.12 \mathrm{ab} \pm 0.07$ \\
\hline
\end{tabular}

Note: Different letter within a row indicate significant difference between the means of three replicates \pm standard error using Turkey's test at $p \leq 0.05$.

Table 9. Water levels on selected chemical properties of soil with and without biochar

\begin{tabular}{|c|c|c|c|c|c|c|c|c|c|}
\hline TRT & Total $\mathbf{N}$ & $\begin{array}{l}\text { Exchangeable } \\
\mathrm{NH}_{4}{ }^{+} \\
\end{array}$ & $\begin{array}{l}\text { Exchangeable } \\
\mathrm{NO}_{3}^{-}\end{array}$ & $\begin{array}{l}\text { Exchangeable } \\
\mathrm{Mg}\end{array}$ & $\begin{array}{l}\text { Exchangeable } \\
\mathrm{Fe}\end{array}$ & $\begin{array}{l}\text { Exchangeable } \\
\mathrm{Na}\end{array}$ & $\begin{array}{l}\text { Exchangeable } \\
\text { Ca }\end{array}$ & $\begin{array}{l}\text { Exchangeable } \\
\mathrm{Cu}\end{array}$ & $\begin{array}{l}\text { Exchangeable } \\
\text { Mn }\end{array}$ \\
\hline & ....\%.... & \multicolumn{2}{|c|}{$\ldots \ldots \ldots \ldots \ldots \ldots \mathrm{mg} \mathrm{kg}^{-1} \ldots \ldots \ldots \ldots \ldots \ldots$} & \multicolumn{6}{|c|}{ 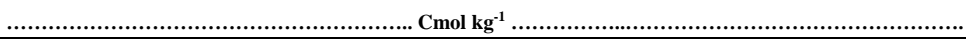 } \\
\hline T1 & $0.39 \mathrm{a} \pm 0.07$ & $16.11 \mathrm{de} \pm 0.7$ & $6.30 \mathrm{~cd} \pm 1$ & $0.69 \mathrm{~b} \pm 0.04$ & $0.02 \mathrm{bc} \pm 0.0002$ & $0.623 \mathrm{a} \pm 0.06$ & $0.93 \mathrm{e} \pm 0.05$ & $7.56 \mathrm{a} \pm 0.8$ & $0.04 \mathrm{bcd} \pm 0.002$ \\
\hline $\mathbf{T 2}$ & $0.29 \mathrm{ab} \pm 0.02$ & $56.04 \mathrm{bcde} \pm 3.31$ & $5.37 \mathrm{~d} \pm 0.9$ & $0.92 \mathrm{a} \pm 0.04$ & $0.012 \mathrm{~cd} \pm 0.0004$ & $0.55 \mathrm{ab} \pm 0.06$ & $1.63 \mathrm{~cd} \pm 0.03$ & $9.86 a \pm 0.56$ & $0.056 a \pm 0.002$ \\
\hline T3 & $0.25 \mathrm{ab} \pm 0.04$ & $90.6 \mathrm{abc} \pm 3.5$ & $6.77 \mathrm{~cd} \pm 0.23$ & $0.92 \mathrm{a} \pm 0.06$ & $0.013 \mathrm{~cd} \pm 0.002$ & $0.58 \mathrm{a} \pm 0.02$ & $1.87 \mathrm{bcd} \pm 0.1$ & $11.2 \mathrm{a} \pm 0.82$ & $0.043 \mathrm{bcd} \pm 0.001$ \\
\hline T4 & $0.28 \mathrm{ab} \pm 0.05$ & $113.9 \mathrm{a} \pm 4.7$ & $5.83 \mathrm{~cd} \pm 0.23$ & $0.85 \mathrm{ab} \pm 0.05$ & $0.011 \mathrm{~cd} \pm 0.0004$ & $0.52 \mathrm{abc} \pm 0.03$ & $2.04 \mathrm{abc} \pm 0.1$ & $9.02 a \pm 1.03$ & $0.036 \mathrm{~d} \pm 0.003$ \\
\hline T5 & $0.27 \mathrm{ab} \pm 0.02$ & $117.5 \mathrm{a} \pm 3.8$ & $9.57 \mathrm{bcd} \pm 0.62$ & $0.85 \mathrm{ab} \pm 0.04$ & $0.0096 \mathrm{~cd} \pm 0.002$ & $0.65 a \pm 0.17$ & $2.16 \mathrm{ab} \pm 0.12$ & $7.55 a \pm 0.96$ & $0.043 \mathrm{bcd} \pm 0.002$ \\
\hline T6 & $0.2 \mathrm{ab} \pm 0.04$ & $113.2 \mathrm{a} \pm 2.63$ & $4.67 \mathrm{~d} \pm 0.47$ & $0.96 \mathrm{a} \pm 0.03$ & $0.016 \mathrm{bcd} \pm 0.003$ & $0.4 \mathrm{abcd} \pm 0.06$ & $2.40 \mathrm{a} \pm 0.17$ & $8.71 \mathrm{a} \pm 0.69$ & $0.06 \mathrm{a} \pm 0.001$ \\
\hline $\mathbf{T} 7$ & $0.23 \mathrm{ab} \pm 0.01$ & $8.87 \mathrm{e} \pm 1.68$ & $6.07 \mathrm{~cd} \pm 0.47$ & $0.39 \mathrm{c} \pm 0.005$ & $0.08 \mathrm{a} \pm 0.004$ & $0.26 \mathrm{bcd} \pm 0.02$ & $1.6 \mathrm{~d} \pm 0.08$ & $8.71 \mathrm{a} \pm 0.56$ & $0.053 \mathrm{ab} \pm 0.001$ \\
\hline T8 & $0.16 \mathrm{~b} \pm 0.03$ & $41.1 \mathrm{cde} \pm 13.1$ & $25.69 \mathrm{a} \pm 2.23$ & $0.414 \mathrm{c} \pm 0.02$ & $0.015 \mathrm{bcd} \pm 0.002$ & $0.23 \mathrm{~cd} \pm 0.03$ & $1.7 \mathrm{~cd} \pm 0.11$ & $9.13 a \pm 0.96$ & $0.042 \mathrm{bcd} \pm 0.003$ \\
\hline T9 & $0.11 b \pm 0.03$ & $50.2 \mathrm{bcde} \pm 19.1$ & $21.25 \mathrm{a} \pm 1.17$ & $0.39 \mathrm{c} \pm 0.02$ & $0.01 \mathrm{~cd} \pm 0.0005$ & $0.24 \mathrm{~cd} \pm 0.01$ & $1.67 \mathrm{~cd} \pm 0.03$ & $10.39 a \pm 0.36$ & $0.04 \mathrm{~d} \pm 0.002$ \\
\hline T10 & $0.10 \mathrm{~b} \pm 0.02$ & $83.6 \mathrm{abc} \pm 15.1$ & $12.61 \mathrm{~b} \pm 2.02$ & $0.36 c \pm 0.005$ & $0.01 \mathrm{~d} \pm 0.0005$ & $0.18 \mathrm{~d} \pm 0.01$ & $1.78 \mathrm{bcd} \pm 0.01$ & $8.60 a \pm 0.46$ & $0.04 \mathrm{~cd} \pm 0.003$ \\
\hline T11 & $0.14 \mathrm{~b} \pm 1$ & $96.9 \mathrm{ab} \pm 16.77$ & $5.18 \mathrm{~d} \pm 0.66$ & $0.37 c \pm 0.03$ & $0.009 \mathrm{~d} \pm 0.0004$ & $0.23 \mathrm{~cd} \pm 0.001$ & $1.79 \mathrm{bcd} \pm 0.05$ & $9.76 a \pm 0.66$ & $0.043 \mathrm{bcd} \pm 0.002$ \\
\hline T12 & $0.18 \mathrm{~b} \pm 0.06$ & $64.91 \mathrm{abcd} \pm 17.8$ & $10.74 b c \pm 0.23$ & $0.4 \mathrm{c} \pm 0.007$ & $0.02 \mathrm{~b} \pm 0.001$ & $0.25 \mathrm{bcd} \pm 0.02$ & $2.01 \mathrm{abcd} \pm 0.02$ & $8.4 \mathrm{a} \pm 0.56$ & $0.052 \mathrm{abc} \pm 0.002$ \\
\hline
\end{tabular}

Note: Different letter within a row indicate significant difference between the means of three replicates \pm standard error using Turkey's test at $p \leq 0.05$.

\section{Conclusion}

There was no urea hydrolysis in the soil without water. Chicken litter biochar as soil amendment effectively mitigated ammonia loss at $1 \%$ to $32 \%$ and $80 \%$ to $115 \%$ field capacity. However, urea used on soil only showed lower ammonia loss at $33 \%$ to $79 \%$ and $116 \%$ to $125 \%$ field capacity compared with the soils with chicken litter biochar. At 50\% field capacity, ammonia loss was high in soils with and without chicken litter biochar. Although chicken litter biochar is reputed for improving soil chemical properties, water levels in this present study affected soil chemical properties differently. Fifty percent field capacity, significantly reduced soil chemical properties. These findings suggest that timely application of urea at the right field capacity can mitigate ammonia emission. Therefore, whether soils are amended with or without chicken litter biochar, urea application should be avoided at $50 \%$ field capacity especially in irrigated crops.

\section{Conflict of Interests}

The authors declare that there is no conflict of interests regarding the publication of this paper.

\section{Acknowledgment}

Authors would like to acknowledge Ministry of Higher Education (FRGS - 5524983), Malaysia, and Universiti 
Putra Malaysia for funding this study.

\section{References}

Abalos, D., Sanz-Cobena, A., Misselbrook, T., \& Vallejo, A. (2012). Effectiveness of urease inhibition on the abatement of ammonia, nitrous oxide and nitric oxide emissions in a non-irrigated Mediterranean barley field. Chemosphere, 89, 310-318. https://doi.org/10.1016/j.chemosphere.2012.04.043

Ahmed, O. H., Aminuddin, H., \& Husni, M. H. A. (2006). Ammonia volatilization and ammonium accumulation from urea mixed with zeolite and triple superphosphate. Acta Agric Scand Sect B, Soil Plant Sci., 58, 182-186. https://doi.org/10.1080/09064710701478271

Al-Kanani, T., MacKenzie, A. F., \& Barthakur, N. N. (1991). Soil water and ammonia volatilization relationships with surface-applied nitrogen fertilizer solutions. Soil Science Society of America Journal, 55, 1761-1766. https://doi.org/10.2136/sssaj1991.03615995005500060043x

Amonette, J. E., \& Joseph, S. (2009). Characteristics of biochar: microchemical properties. Biochar for environmental management: Science and technology, 33.

Asada, T., Ishihara, S., Yamane, T., Toba, A., Yamada, A., \& Oikawa, K. (2002). Science of bamboo charcoal: study on carbonizing temperature of bamboo charcoal and removal capability of harmful gases. Journal of health science, 48(6), 473-479. https://doi.org/10.1248/jhs.48.473

Bremner, J. M. (1965). Total Nitrogen. In C.A. Black, D. D. Evan, L.E. Ensminger, J. L. White, F. E. Clark, \& R. D. Dinauer (Eds.), Method of soil analysis part 2, (pp. 1149-1178). American Society of Agronomy. Madison, Wisconcin.

Bremner, J. M. (1995). Recent research on problems in the use of urea as a nitrogen fertilizer. Fert. Res., 42, 321-329.

Cameron, K. C., Di, H. J., \& Moir, J. L. (2013). Nitrogen losses from the soil/plant system: a review. Annals of Applied Biology, 162(2), 145-173. https://doi.org/10.1111/aab.12014

Chefetz, B., Hatcher, P. G., Hadar, Y., \& Chen, Y. (1996). Chemical and biological characterization of organic matter during composting of municipal solid waste. Journal of Environmental Quality, 25(4), 776-785. https://doi.org/10.2134/jeq1996.00472425002500040018x

Cheng, C. H., Lehmann, J., \& Engelhard, M. H. (2008). Natural oxidation of black carbon in soils: changes in molecular form and surface charge along a climosequence. Geochimica et Cosmochimica Acta., 72(6), 1598-1610. https://doi.org/10.1016/j.gca.2008.01.010.

Clough, T. J., Bertram, J. E., Ray, J. L., Condron, L. M., O’Callaghan, M., Sherlock, R. R., \& Wells, N. S. (2010). Unweathered biochar impact on nitrous oxide emissions from a bovine-urine-amended pasture soil. Soil Sci. Soc. Am. J., 74, 852-860. https://doi.org/10.2136/sssaj2009.0185

Cottenie, A. (1980). Soil testing and plant testing as a basis for fertilizer recommendation. FAO Soil Bull., 38, 70-73.

Fan, M. X., \& Mackenzie, A. F. (1993). Urea and phosphate interactions in fertilizer microsites: ammonia volatilization and $\mathrm{pH}$ changes. Soil Science Society of America Journal, 57(3), 839-845. https://doi.org/10.2136/sssaj1993.03615995005700030034x

Francisco, S. S., Urrutia, O., Martin, V., Peristeropoulos, A., \& Garcia-Mina, J. M. (2011). Efficiency of urease and nitrification inhibitors in reducing ammonia volatilization from diverse nitrogen fertilizers applied to different soil types and wheat straw mulching. J. Sci. Food Agric., 91, 1569-1575.

https://doi.org/10.1002/jsfa.4349

Gaskin, J. W., Steiner, C., Harris, K., Das, K. C., \& Bibens, B. (2008). Effect of low-temperature pyrolysis conditions on biochar for agricultural use. Transactions of the ASABE, 51(6), 2061-2069.

Gill, J. S., Khind, B.-S., \& Yadvinder-Singh, C. S. (1999). Efficiency of N-(n-butyl) thiophosphoric triamide in retarding hydrolysis of urea and ammonia volatilization losses in a flooded sandy loam soil amended with organic materials. Nutr. Cycling Agroecosyst., 53, 203-207.

Glibert, P. M., Harrison, J., Heil, C., \& Seitzinger, S. (2006). Escalating worldwide use of urea - a global change contributing to coastal eutrophication. Biogeochemistry, 77, 441-463.

Harris, P. J. (1997). Structure of non-graphitising carbons. International Materials Reviews, 42(5), 206-218. https://doi.org/10.1179/imr.1997.42.5.206 
Harris, P. J., \& Tsang, S. C. (1997). High-resolution electron microscopy studies of non-graphitizing carbons. Philosophical Magazine A, 76(3), 667-677. https://doi.org/10.1080/01418619708214028

Havlin, J. L., Beaton, J. D., Tisdale, S. L., \& Nelson, W. L. (1999). Soil fertility and fertilizers: An introduction to nutrient management. Sixth ed. Upper Saddle River, NJ: Prentice Hall.

Jensen, L. S., Schjoerring, J. K., van der Hoek, K. W., Poulsen, H. D., Zevenbergen, J. F., Palliere, C., \& van Grinsven, H., (2011). Benefits of nitrogen for food, fibre and industrial production. In Sutton, M. A., Howard, C. M., Erisman, J. W., Billen, G., Bleeker, A., Grennfelt, P., van Grinsven, H., \& Grizzetti, B. (Eds.), The European Nitrogen Assessment (pp. 35-36), Cambridge University Press, Cambridge, UK.

Jia, X., Yuan, W., \& Ju, X. (2015). Effects of Biochar Addition on Manure Composting and Associated N2O Emissions. Journal of Sustainable Bioenergy Systems, 5(02), 56. http://dx.doi.org/10.4236/jsbs.2015.52005

Keeney, D. R., \& Nelson, D. W. (1982). Nitrogen- Inorganic Forms. In A. L. Page, D. R. Keeney, D. E. Baker, R. H. Miller, R. Jr. Ellis, \& D. J. Rhoades (Eds.), Methods of Soil Analysis, Part 2, Madison: Agronomy Monograph 9, ASA and SSSA, Madison, Wisconsin, USA.

Lehmann J. (2007). Bio-energy in the black. Front Ecol Environ., 5, 381-387.

Liyanage, L. R. M. C., Jayakody, A. N., \& Gunaratne, G. P. (2015). Ammonia volatilization from frequently applied fertilizers for the low-country tea growing soils of Sri Lanka. Tropical Agricultural Research, 26(1).

MADA (1970, June 30). Muda Agricultural Development Authority. Paddy, fertilization. Retrieved from http://www.mada.gov.my/semakan-tanaman-padi

Madrini, B., Shibusawa, S., Kojima, Y., \& Hosaka, S. (2016). Effect of natural zeolite (clinoptilolite) on ammonia emissions of leftover food-rice hulls composting at the initial stage of the thermophilic process. 農業気争, 72(1), 12-19. https://doi.org/10.2480/agrmet.D-15-00012

Martins, M. R., Jantalia, C. P., Polidoro, J. C., Batista, J. N., Alves, B. J., Boddey, R. M., \& Urquiaga, S. (2015). Nitrous oxide and ammonia emissions from $\mathrm{N}$ fertilization of maize crop under no-till in a Cerrado soil. Soil and Tillage Research, 151, 75-81. https://doi.org/10.1016/j.still.2015.03.004

Maru, A., Haruna, O. A., \& Charles, P. W. (2015). Coapplication of Chicken Litter Biochar and Urea Only to Improve Nutrients Use Efficiency and Yield of Oryza sativa L. Cultivation on a Tropical Acid Soil. The Scientific World Journal, 2015. http://dx.doi.org/10.1155/2015/943853

Murphy, J., \& Riley, J. P. (1962). A modified single solution method for the determination of phosphate in natural waters. Analytical Chemistry Acta, 27, 31-36. https://doi.org/10.1016/S0003-2670(00)88444-5

Palanivell, P., Ahmed, O. H., \& Ab Majid, N. M. (2016). Minimizing ammonia volatilization from urea, improving lowland rice (cv. MR219) seed germination, plant growth variables, nutrient uptake, and nutrient recovery using clinoptilolite zeolite. Archives of Agronomy and Soil Science, 62(5), 708-724. https://doi.org/10.1080/03650340.2015.1077229

Palanivell, P., Ahmed, O. H., \& Ab Majid, N. M. (2017). Minimizing Ammonia Volatilization from Urea in Waterlogged Condition Using Chicken Litter Biochar. Communications in Soil Science and Plant Analysis, 48(17), 1-10. https://doi.org/10.1080/00103624.2017.1406497

Peech, H. M. (1965). Hydrogen-ion Activity. In C. A. Black, D. D. Evan, L. E. Ensminger, J. L. White, F. E. Clark, \& R. C. Dinaue (Eds.), Method of Soil Analysis, Part 2, (pp. 914-926). Ithaca: American society of Agronomy, Madison, Wisconsin.

Rebecca R. (2007). Rethinking biochar. Environ Sci Technol., 41, 6032-6033. https://doi.org/10.1080/03650340.2013.789870

Rondon, M. A., Molina, D., Hurtado, M., Ramirez, J., Lehmann, J., Major, J., \& Amezquita, E. (2006). Enhancing the productivity of crops and grasses while reducing greenhouse gas emissions through bio-char amendments to unfertile tropical soils.

Rowell, D. (1994). Soil Science; Methods and Applications, Department of Soil Science, University of Reading.

SAS, (2011). SAS/STAT Ssoftware. SAS Institute, (2nd ed.) Cary, NC.16.

Siva, K. B., Aminuddin, H., Husni, M. H. A., \& Manas, A. R. (1999). Ammonia volatilization from urea as affected by tropical - based palm oil mill effluent (Pome) and peat. Communications in Soil Science \& Plant Analysis, 30(5-6), 785-804. https://doi.org/10.1080/00103629909370246

Sommer, S. G., \& Hutchings, N. J. (2001). Ammonia emission from field applied manure and its reduction - 
invited paper. Eur. J. Argon., 15, 1-15. https://doi.org/10.1016/S1161-0301(01)00112-5

Sommer, S. G., McGinn, S. M., Hao, X., \& Larney, F. J. (2004). Techniques for measuring gas emissions from a composting stockpile of cattle manure. Atmos. Environ., 38(28), 4643-4652.

https://doi.org/10.1016/j.atmosenv.2004.05.014

Sommer, S. G., Schjoerring, J. K., \& Denmead, O. T. (2004). Ammonia emission from mineral fertilizers and fertilized crops. Adv. Agron., 82, 557-622.

Tan, K. H. (2005). Soil Sampling, Preparation and Analysis. (2nd ed.), pp. 154-174 (1-623). Taylor and Francis Group. Boca Raton, Florida, USA, CRC Press,

Van Zwieten, L., Singh, B., Joseph, S., Kimber, S., Cowie, A., \& Chan, K. Y. (2009). Biochar and emissions of non-CO2 greenhouse gases from soil. Biochar for environmental management: science and technology, 1 , 227-250.

Xu, J. M., Tang, C., \& Chen, Z. L. (2006). The role of plant residues in $\mathrm{pH}$ change of acid soils differing in initial pH. Soil Biology and Biochemistry, 38(4), 709-719. https://doi.org/10.1016/j.soilbio.2005.06.022

\section{Copyrights}

Copyright for this article is retained by the author(s), with first publication rights granted to the journal.

This is an open-access article distributed under the terms and conditions of the Creative Commons Attribution license (http://creativecommons.org/licenses/by/3.0/). 